Biogeosciences Discuss., doi:10.5194/bg-2016-223, 2016

Manuscript under review for journal Biogeosciences

Published: 20 June 2016

(c) Author(s) 2016. CC-BY 3.0 License.

\title{
Feasibility for detection of ecosystem response to disturbance by atmospheric carbon dioxide
}

\author{
Bjorn-Gustaf J. Brooks ${ }^{1}$, Ankur R. Desai ${ }^{2}$, Britton B. Stephens ${ }^{3}$, Anna M. Michalak ${ }^{4}$, and \\ Jakob Zscheischler ${ }^{5}$ \\ ${ }^{1}$ US Department of Agriculture-Forest Service, Southern Research Station, Asheville, NC, USA \\ ${ }^{2}$ Department of Atmospheric and Oceanic Sciences, University of Wisconsin-Madison, Madison, WI, USA \\ ${ }^{3}$ National Center for Atmospheric Research, Boulder, CO, USA \\ ${ }^{4}$ Department of Global Ecology, Carnegie Institution for Science, Stanford, CA, USA \\ ${ }^{5}$ Institute for Atmospheric and Climate Science, ETH Zurich, Zurich, Switzerland
}

Correspondence to: Bjorn Brooks (bjorn@geobabble.org)

\begin{abstract}
Monitoring the terrestrial carbon cycle for responses to disturbances, caused for example by extreme climate events and insect outbreaks, has the potential to provide early warnings about ecosystem change. However, our capability to detect these carbon balance responses by atmospheric $\mathrm{CO}_{2}$ monitoring remains unknown despite sub-ppm comparability of many well-calibrated $\mathrm{CO}_{2}$ measurement sites. Here, this study explores how accurately atmospheric $\mathrm{CO}_{2}$ and transport models can detect imposed carbon flux anomalies against a background terrestrial flux. Air mass back trajectories from three $\mathrm{CO}_{2}$ monitoring stations in the central U.S. Rocky Mountains for one year (2008) were computationally simulated. To simulate reduced $\mathrm{CO}_{2}$ uptake, a constant $+0.2 \mu \mathrm{mol} \mathrm{C} \mathrm{m}^{-2} \mathrm{~s}^{-1}$ anomaly was added to all surface fluxes within perturbation domains of varying size. A spatially and temporally uniform $10^{\circ} \times 10^{\circ}+0.2 \mu \mathrm{mol} \mathrm{C} \mathrm{m}^{-2} \mathrm{~s}^{-1}$ flux anomaly $\left(+6 \mathrm{TgC} \mathrm{mo}^{-1}\right)$ was detectable above a comprehensive model-data mismatch detection threshold in a large majority of months at each site, but only when the perturbation was located in the central Mountain West. The intensity of the perturbation and its area were important to detection, but the effect of area declined exponentially with increasing source-to-station distance. To further evaluate response, a more realistic spatio-temporally varying drought extracted from a dynamic global vegetation model with a monthly varying perturbation area $\left(1^{\circ} \times 1^{\circ}\right.$ to $\left.5^{\circ} \times 5^{\circ}\right)$ and higher peak intensity $\left(+0.8 \mu \mathrm{mol} \mathrm{C} \mathrm{m}{ }^{-2} \mathrm{~s}^{-1}\right)$ was applied. Detectability of excess $\mathrm{CO}_{2}$ from this experiment by the nearest $\mathrm{CO}_{2}$ site (Utah) was similar to detectability of the largest $\left(10^{\circ} \times 10^{\circ}\right)$ uniform perturbation. These experiments demonstrate disturbance and drought related carbon-cycle perturbations do create a discernible impact on the composite signal of atmospheric $\mathrm{CO}_{2}$ if sufficiently proximal to a measurement station.
\end{abstract}

\section{Introduction}

The increasing burden of anthropogenic carbon dioxide emissions in the atmosphere, leading to global climate change, is partially offset by the terrestrial carbon sink (Pan et al., 2011; Le Quéré et al., 2013). The magnitude and variability of this sink is strongly sensitive to impacts from ecological disturbance and extreme climate events (Bonan, 2008; Martínez-Vilalta et al., 2012; Reichstein et al., 2013; Gatti et al., 2014; Wang et al., 2014), both of which are projected to increase in a changing 
Biogeosciences Discuss., doi:10.5194/bg-2016-223, 2016

Manuscript under review for journal Biogeosciences

Published: 20 June 2016

(c) Author(s) 2016. CC-BY 3.0 License.

climate (Diffenbaugh and Field, 2013). In particular, ecosystems that are geographically or topographically near the edges of their niches or in regions with high rates of climate change may be most likely to suffer from changes in the frequency of events that stress plant productivity or enhance rates of decomposition (Allen et al., 2010; Walter et al., 2013). Forests and grasslands in the Western United States meet these criteria and are particularly vulnerable to changes in frequency and intensity of drought (van der Molen et al., 2011), wildfire (Jolly et al., 2015), and disturbances from insect outbreaks (Harte et al., 2006; van Mantgem et al., 2009; Hicke et al., 2012).

However, it has been difficult to assess the climate and disturbance sensitivity of the carbon cycle of these ecosystems owing to the large spatial scale, complex terrain leading to heterogeneous biogeography (Göckede et al., 2006), and lack of sufficient long-term observations. Consequently, several efforts are underway to monitor western North American forests and grasslands from space, monitoring plots, and flux towers (e.g., ForWarn, National Insect and Disease Risk Map, MODIS Global Disturbance Index, Global Fire Emission Database). One promising approach is the use of atmospheric inversions for detection of changes in regional carbon balance (Ciais et al., 2010; Peters et al., 2010). While global tracer-transport inversions, based on inferring surface fluxes from the global network of $\mathrm{CO}_{2}$ measurement sites and large-scale transport models, have been employed in diagnosing the magnitude of regional carbon sources and sinks (Peters et al., 2010; Hayes et al., 2012), there has been less study on their reliability for detecting changes to regional carbon sinks in response to major disturbances (Ciais et al., 2005). Prior work has shown that mountaintop $\mathrm{CO}_{2}$ observations, such as those used in this study, can be used in regional and global inversions to improve capabilities to resolve regional carbon sources and sinks (Brooks et al., 2012). Here, we ask: To what extent and with what precision can these $\mathrm{CO}_{2}$ observations tell us anything about the sensitivity of regional mountain carbon fluxes to the effects of large-scale disturbance and climate extremes such as drought?

The analysis here does not resolve the underlying mechanisms that drive changes in terrestrial net ecosystem exchange (NEE) of $\mathrm{CO}_{2}$, but rather what factors of atmospheric $\mathrm{CO}_{2}$ monitoring network design (location and measurement compatibility) and atmospheric transport fidelity are needed to observe carbon flux changes in intensity, spatial extent, and geographical coverage. We examine whether these Mountain West $\mathrm{CO}_{2}$ stations (Hidden Peak, Utah; Niwot Ridge T-Van, Colorado; Storm Peak Laboratory, Colorado) are sufficiently sensitive to capture the effects of short-lived and persistent climate extremes on the carbon-cycle for proximal and distant perturbations.

\section{Methods}

In these simulated experiments, a Lagrangian trajectory model (STILT) coupled with a regional meteorological model (WRF) was used to simulate backward Lagrangian particle trajectories for one year from three continuous $\mathrm{CO}_{2}$ observing stations in the Mountain West that are part of the Regional Autonomous Continuous $\mathrm{CO}_{2}$ Network in the Rocky Mountains (Rocky RACCOON). Simulated carbon fluxes from the NOAA CarbonTracker inverse model (CT2013, Peters et al., 2007, http://carbontracker.noaa.gov) were convolved with $1^{\circ} \times 1^{\circ}$ WRF-STILT back trajectories to generate spatially and temporally explicit $\mathrm{CO}_{2}$ values estimating the amount of $\mathrm{CO}_{2}$ that each $1^{\circ} \times 1^{\circ}$ location and time contributed to the $\mathrm{CO}_{2}$ measured at a RACCOON station. To simulate differently located droughts fluxes were perturbed over different domains and intensities. 
Biogeosciences Discuss., doi:10.5194/bg-2016-223, 2016

Manuscript under review for journal Biogeosciences

Published: 20 June 2016

(c) Author(s) 2016. CC-BY 3.0 License.

The spatial aggregate of these perturbed $\mathrm{CO}_{2}$ values when subtracted from the unperturbed case revealed the excess atmospheric $\mathrm{CO}_{2}$ that is expected to be observed at that station given transport as simulated by WRF-STILT. For the first set of perturbations a uniform flux anomaly was imposed with an intensity equivalent to the difference between the annual mean of the strongest and weakest carbon uptake years from CarbonTracker's (CT2013) biospheric $\mathrm{CO}_{2}$ fluxes (Table 1, Fig. 1). In addition a space and time varying prototypical perturbation, i.e. a drought, was also imposed and compared. The uniform flux anomaly was applied to all grid cells within the perturbation domain with equal intensity throughout the year. The prototypical drought on the other hand, had a monthly varying intensity and spatially variable pattern based on data taken directly from the VEgetation-Global-Atmosphere-Soil terrestrial carbon cycle model (VEGAS, Zeng, 2003; Zeng et al., 2004, 2005), which simulates vegetation growth and competition in addition to the full terrestrial carbon cycle for predicting decadal-scale feedbacks to climate variability.

The primary goal of this study was to evaluate how strongly carbon flux anomalies would appear relative to a comprehensive model-data mismatch uncertainty threshold based on the error associated with the ability to model atmospheric concentrations observed at specific measurement sites (which include not only the measurement error, but also transport model error, aggregation error, and representation error). Results in the main paper are evaluated over monthly timescales. We additionally show in the Appendix our results at 3-hourly timescales against a measurement error threshold that is based on the uncertainty of the atmospheric observations themselves.

\section{$2.1 \quad \mathrm{CO}_{2}$ observing station descriptions}

The three $\mathrm{CO}_{2}$ measurement stations used in this study (Fig. A5) are part of the RACCOON Network. Each station has a well-calibrated $\mathrm{CO}_{2}$ sampling system (Stephens et al., 2011) maintained by the National Center for Atmospheric Research, and provides coverage in a difficult-to-monitor and under-sampled Western U.S. landscape. More than nine years of sub-hourly $\mathrm{CO}_{2}$ profile observations are available from locations spanning Colorado, Utah, and Arizona. High elevation, multiple inlet heights and fast sampling allow these $\mathrm{CO}_{2}$ observations to be filtered and used as constraints within data assimilation model systems. The three RACCOON stations for this study represent high elevation locations in Colorado and Utah. NWR T-Van site is a ridge-top station (3523 m.a.s.l.) located above tree-line on Niwot Ridge $5 \mathrm{~km}$ west and $470 \mathrm{~m}$ higher than the Niwot Ridge AmeriFlux Forest Site. SPL (Storm Peak Laboratory, 3210 m.a.s.l.) samples mountaintop air $100 \mathrm{~km}$ to the northwest near Steamboat Springs, Colorado. HDP (Hidden Peak, 3351 m.a.s.l.) lies $30 \mathrm{~km}$ southeast and $2054 \mathrm{~m}$ above the center of Salt Lake City, Utah. This network has included an additional valley site in Colorado and mountaintop site in Arizona, not discussed here. Further details and data from these stations are hosted online at http://raccoon.ucar.edu.

\section{2 $\mathrm{CO}_{2}$ observing station influence functions}

Influence functions are probabilistic representations of the sensitivity of available observations to upwind fluxes, and are derived using the back-trajectories of virtual transported particles. We examined the influence of points across a $1^{\circ} \mathrm{x} 1^{\circ}$ gridded domain $\left(170^{\circ}-50^{\circ} \mathrm{W}\right.$ longitude, $10^{\circ}-70^{\circ} \mathrm{N}$ latitude) at 3-hourly resolution for the year 2008 . These influence functions were the 
Biogeosciences Discuss., doi:10.5194/bg-2016-223, 2016

Manuscript under review for journal Biogeosciences

Published: 20 June 2016

(c) Author(s) 2016. CC-BY 3.0 License.

same as those used in Chatterjee et al. (2012) and Shiga et al. (2013) and were calculated by the Stochastic Time-Inverted Lagrangian Transport model, STILT, coupled to WRF (Lin et al., 2003; Nehrkorn et al., 2010).

Each hourly WRF-STILT time step provided 240 prior hours (10 days x 24 hours) of back trajectory data for each RACCOON station representing the gridded particle locations at past hourly time points for all 500 particles that were released. We truncated our backward time horizon to the most recent 3 days, which focused our analysis on the continental flux influences rather than the Pacific Ocean (Fig. A6). The final step prior to convolution with surface fluxes was to aggregate the back trajectories to generate influence functions, which represent summed and corrected boundary-layer particle masses aggregated over each prior 3 day window. These back trajectories simulated each station at its ground-relative height above the STILT model surface (18, 5, and 9 m.a.g.l. for HDP, NWR and SPL, respectively).

\section{3 $\mathrm{CO}_{2}$ flux estimates from CarbonTracker}

Regional ecosystem carbon flux estimates from CT2013 (Peters et al., 2007, with updates described at http://carbontracker. noaa.gov) were used as our baseline carbon fluxes. CT2013 is an ensemble Kalman filter data assimilation system that combines observations of atmospheric $\mathrm{CO}_{2}$ with ecological and atmospheric transport models to determine suitable $\mathrm{CO}_{2}$ flux estimates that best fit observed $\mathrm{CO}_{2}$ mixing ratio constraints. CT2013 uses data from HDP, NWR, and SPL, among many other CO 2 measurement stations, as constraints in its optimization. In order to determine each $\mathrm{CO}_{2}$ site's sensitivity it was necessary to apply a flux perturbation to the CT2013 fluxes. For the first set of perturbations the flux anomaly was a constant applied to all grid cells within each perturbation domain. We chose to use a value equal to regional interannual variability of the carbon cycle. To determine this value we calculated the CT2013 mean annual ecosystem fluxes for a western domain from $100^{\circ}-115^{\circ} \mathrm{W}$, and $35^{\circ}-50^{\circ} \mathrm{N}$ for years 2000-2010 (Table 1, Fig. 1) and took the difference between the minimum and maximum of all years to be our nominal perturbation intensity. This amounted to $+0.2 \mu \mathrm{mol} \mathrm{C} \mathrm{m}{ }^{-2} \mathrm{~s}^{-1}$ and is referred to as the uniform flux anomaly.

\subsection{Convolution of $\mathrm{CO}_{2}$ fluxes and influence functions}

For each $\mathrm{CO}_{2}$ measurement station during the 2008 year CT2013 ecosystem fluxes were multiplied by the corresponding WRF-STILT influence function values to develop spatially explicit $\left(1^{\circ} \mathrm{x} 1^{\circ}\right)$ values of $\mathrm{CO}_{2}$ contributions (ppm). These data indicate the locations and amounts of $\mathrm{CO}_{2}$ that in theory contributed to the total $\mathrm{CO}_{2}$ concentration observed at a particular measurement location and time.

Convolution was done by an algorithm that stepped through each day of data and multiplied the ecosystem fluxes $\left(\mu \mathrm{mol} \mathrm{C} \mathrm{m}^{-2} \mathrm{~s}^{-1}\right.$ ) by their corresponding influence functions ( $\mathrm{ppm} \mu \mathrm{mol}^{-1} \mathrm{~m}^{2} \mathrm{~s}^{1}$ ). To match the differing hourly and 3-hourly sampling rates the previous three days of ecosystem fluxes were interpolated to an hourly time step using a cubic spline function. At each time step (hour) for the 2008 year the previous 72 hours of ecosystem fluxes were multiplied against the corresponding 72 hours of back-trajectory influence functions to obtain the gridded $\mathrm{CO}_{2}$ values, which can be summed over space and time to give the total $\mathrm{CO}_{2}$ contribution for the modeled domain at that time step. 
Biogeosciences Discuss., doi:10.5194/bg-2016-223, 2016

Manuscript under review for journal Biogeosciences

Published: 20 June 2016

(c) Author(s) 2016. CC-BY 3.0 License.

To illustrate the convolution products Fig. 2 provides four snapshot maps of $\mathrm{CO}_{2}$ simulated to have contributed to the total $\mathrm{CO}_{2}$ arriving at NWR at 08:00 LT on 12 July. Figs. 2a-c reveal upwind sinks from 36-34 hours prior to 08:00 LT that contributed air depleted in $\mathrm{CO}_{2}$ relative to background concentrations, whereas at 33 hours prior (Fig. 2d) a source contributed additional $\mathrm{CO}_{2}$ to the air mass simulated to arrive at NWR. Collectively these air masses (virtual particles) and their composite signal represents the amount of biospheric influence over the previous three days on atmospheric $\mathrm{CO}_{2}$ at $\mathrm{NWR}$ at 08:00 LT. Four ecoregion types including grass/shrub, conifer forest, semi tundra, and crops were represented within the area of influence in CarbonTracker's land classification scheme (Gibbs, 2006). In addition to ecoregion type, Fig. 2 implicitly includes biospheric and environmental effects (e.g., PAR, precipitation) based on variable weather conditions at those times. Fig. 2 does not, however, indicate information about disturbance history or land-use changes.

\subsection{Excess- $\mathrm{CO}_{2}$ from a uniform flux anomaly}

As described above the total range in central Mountain West $\mathrm{CO}_{2}$ flux variability from CT2013 was used to determine the intensity of the uniform flux anomaly, $+0.2 \mu \mathrm{mol} \mathrm{C} \mathrm{m}{ }^{-2} \mathrm{~s}^{-1}$. We found that this value is reasonable by comparison to regionally averaged NEE (16 AmeriFlux forest and grassland sites representing $100^{\circ}-115^{\circ} \mathrm{W}, 35^{\circ}-50^{\circ} \mathrm{N}$ ) that varied over the observational record on a monthly basis from about -3 to $+1 \mu \mathrm{mol} \mathrm{C} \mathrm{m}{ }^{-2} \mathrm{~s}^{-1}$ (daily from -10 to $+7 \mu \mathrm{mol} \mathrm{Cm} \mathrm{m}^{-2} \mathrm{~s}^{-1}$, and half-hourly from -27 to $+26 \mu \mathrm{mol} \mathrm{C} \mathrm{m}{ }^{-2} \mathrm{~s}^{-1}$ ). $+0.2 \mu \mathrm{mol} \mathrm{C} \mathrm{m}^{-2} \mathrm{~s}^{-1}$ represents about $5 \%$ of the regional AmeriFlux monthly range, which is not unrealistic in terms of a persistent flux throughout the year (cf. Ciais et al., 2005, for discussion of coherent regional drought effects on eddy covariance towers). To test the importance of disturbance location perturbations were centered in three different regions (Fig. A5), namely central (Colorado/Utah), southwest (Arizona/New Mexico), and northwest (Oregon/Idaho). For each perturbation location four perturbation sizes were tested each representing an approximate doubling of area $3.5^{\circ} \times 3.5^{\circ}\left(\sim 120,000 \mathrm{~km}^{2}\right), 5^{\circ} \times 5^{\circ}\left(\sim 240,000 \mathrm{~km}^{2}\right), 7^{\circ} \times 7^{\circ}\left(\sim 470,000 \mathrm{~km}^{2}\right)$ and $_{10}^{\circ} \times 10^{\circ}\left(\sim 950,000 \mathrm{~km}^{2}\right)$. The average monthly perturbation magnitudes over these domains are $+0.7 \mathrm{TgC} \mathrm{mo}^{-1},+1.5 \mathrm{TgC} \mathrm{mo}^{-1},+3 \mathrm{TgC} \mathrm{mo}^{-1}$ and $^{-1}$ $+6 \mathrm{TgC} \mathrm{mo}^{-1}$ for the $3.5^{\circ} \times 3.5^{\circ}, 5^{\circ} \times 5^{\circ}, 7^{\circ} \times 7^{\circ}$ and $10^{\circ} \times 10^{\circ}$ perturbation domains respectively. In total this made for 3 (stations) $\times 3$ (locations) $\times 4$ (sizes) $=36$ test cases.

\subsection{Excess- $\mathrm{CO}_{2}$ from a prototypical drought}

Real carbon cycle perturbations (e.g., droughts) have spatially varying patterns and their effects on atmospheric $\mathrm{CO}_{2}$ are varyingly conveyed through the atmosphere to the measurement sites. Duration and intensity of perturbation are also important, as well as the seasonal timing of water limitation and source ( $\mathrm{Hu}$ et al., 2010). Therefore, in addition to the uniform flux anomaly described above, we were interested in how a spatially and temporally realistic carbon cycle extreme might affect our analysis. To do this we obtained $\mathrm{CO}_{2}$ flux extremes from the VEGAS model, forced by observed meteorology (Zeng et al., 2005) run for MsTMIP (Huntzinger et al., 2013), the same data that were examined by Zscheischler et al. (2014). We selected VEGAS out of a set of the ten models examined purely on the basis of carbon cycle perturbations that occurred upwind of, or nearby the RACCOON $\mathrm{CO}_{2}$ monitoring stations. Only one prototypical extreme in net $\mathrm{CO}_{2}$ exchange (caused for example by a drought or a heat wave) from VEGAS was selected according to the following methodology. Flux extremes were identified 
Biogeosciences Discuss., doi:10.5194/bg-2016-223, 2016

Manuscript under review for journal Biogeosciences

Published: 20 June 2016

(c) Author(s) 2016. CC-BY 3.0 License.

by searching anomaly data within the stations' zonal domain $100^{\circ}-115^{\circ} \mathrm{W}$, and $35^{\circ}-45^{\circ} \mathrm{N}$. Following the technique for assessing spatiotemporally contiguous extremes in Earth observation data by Zscheischler et al. (2013) a $\mathrm{CO}_{2}$ flux anomaly subset was preprocessed first by removing the seasonal cycle, trend, and normalizing the data (see Figure 5a in Zscheischler et al., 2013) and filtering for $\mathrm{CO}_{2}$ flux anomalies that were more positive (toward release) than $95 \%$ of the data. Throughout the lat, lon, time data-space of preprocessed values, flux extreme events were identified based on the number of adjacent lat, lon, time pixels that were also 5\% extremes and then ranked by the total integrated flux anomaly. One year of ecosystem flux anomaly data were extracted and applied as a perturbation with intensity, spatial distribution and seasonal duration taken directly from the original VEGAS model output. Because sub-monthly data was not available from VEGAS the prototypical perturbation intensity and extent changed only with each new month. Fig. A7 illustrates the spatial distribution and intensity of the biggest found prototypical drought within the U.S. Mountain West, which lasted three months, had a maximal spatial extent of $260,000 \mathrm{~km}^{2}$, and contained a peak drought intensity of $+0.8 \mu \mathrm{mol} \mathrm{C} \mathrm{m}^{-2} \mathrm{~s}^{-1}$ within the most drought stressed grid cell $\left(0.5^{\circ}\right)$. If aggregated to an annual total (as was done for the uniform flux anomaly) the average monthly perturbation magnitude of the prototypical drought is $+1.6 \mathrm{TgC} \mathrm{mo}^{-1}$. The key differences for the prototypical drought are that it occurred with four times the peak intensity of the uniform flux anomaly, had a varying spatial distribution, and lasted only three months (April, May, June).

\subsection{Detection thresholds}

Two detection thresholds are described here (model-data mismatch and measurement error), each with applicability that depends on the purpose of the analysis. To simplify exposition of our analysis in the main paper we use the model-data mismatch (MDM) detection threshold at monthly timescales. The MDM threshold is station-specific, based on the model-data mismatch values $(1 \sigma)$ for that site, and is relevant for attributing a signal to an anomaly in fluxes. MDM reflects uncertainty in modeled $\mathrm{CO}_{2}$ at each RACCOON site that is due to transport model error, representation error, and aggregation errors from heterogeneous flux influences (Shiga et al., 2014). We define detectability as the ability to distinguish an excess $\mathrm{CO}_{2}$ signal above MDM uncertainty.

The model-data mismatch error variances used for the MDM threshold were derived from a regional inverse modeling study (Shiga et al., 2014) that used the same atmospheric model used here. Shiga et al. (2014) provided $1 \sigma$ values based on 3 hourly averages throughout the 2008 year for HDP $(0.9 \mathrm{ppm})$, NWR $(2.6 \mathrm{ppm})$ and SPL (1.2 ppm) (Table 2, see also supporting information ts01.xlsx in Shiga et al., 2014). These MDM error variances are used to develop monthly detection thresholds relevant to the uncertainty associated with modeling atmospheric concentrations observed at specific measurement sites, which includes not only the measurement error, but also the three other sources of error mentioned above. Although the specific application in Shiga et al. (2014) was different than ours, the errors are expected to be generally representative of uncertainty in this study because identical models and resolutions were used.

The results below are given at monthly timescales, which are relatable to monthly aggregated regional carbon balances and budgets. Monthly excess $\mathrm{CO}_{2}$ values were obtained by averaging 3-hourly values, as $\Sigma / \mathrm{n}$ where $\mathrm{n}=8 * 30=240$. To calculate a reasonable comprehensive detection threshold the MDM error estimates were aggregated differently, however, because trans- 
Biogeosciences Discuss., doi:10.5194/bg-2016-223, 2016

Manuscript under review for journal Biogeosciences

Published: 20 June 2016

(c) Author(s) 2016. CC-BY 3.0 License.

port model errors are autocorrelated over hourly timescales (Lauvaux et al., 2009), which is problematic when comparing to high-frequency observations. To compensate we calculated a standard error for the monthly sample size parsimoniously using $\mathrm{n}=30$. Thus, we divided each site's MDM $1 \sigma$ value by $\sqrt{30}$ to represent a month of daily values in which each day is statistically independent. The monthly mean detection thresholds, therefore, are $0.16 \mathrm{ppm}$ for HDP, $0.47 \mathrm{ppm}$ for NWR, and $0.22 \mathrm{ppm}$ for SPL (Table 2). While results in Fig. 3 are aggregated across all 3 sites (with no detection threshold for comparison), Fig. 4 breaks the data down by individual sites with comparison to their MDM $\sigma / \sqrt{\mathrm{n}}$ detection thresholds.

Our additional measurement error threshold appears in supplementary Fig. A11 in the Appendix where 3-hourly data are reported, which are closer to the timescale of the measurement detection threshold. Although the measurement threshold has relevance for detecting anomalies over shorter timescales it is important to consider that it does not account for the sources of uncertainty as comprehensively as the MDM threshold. Measurement error (compatibility) is based on a $1 \sigma$ uncertainty over 100 seconds of $1 \mathrm{~Hz}$ observations, which is $0.2 \mathrm{ppm}$, and was determined though NOAA flask sample comparisons from NWR. Since all RACCOON stations are based on the same sampling platform (Stephens et al., 2006, 2011) and reference gas standards the measurement error threshold reflects the amount of uncertainty to be expected from two RACCOON sites measuring air with identical $\mathrm{CO}_{2}$ concentrations. Previous work has shown $\mathrm{CO}_{2}$ data from these RACCOON stations are

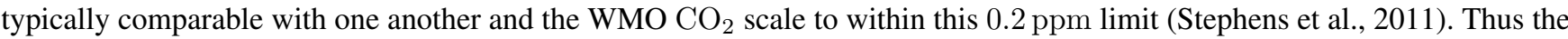
measurement threshold is useful for detecting an anomaly in $\mathrm{CO}_{2}$ observations, where any atmospheric transport biases are assumed to be constant.

\section{Results and Discussion}

\subsection{Effects of perturbation location and area on detection}

20 The most evident outcome of our simulation experiments was that shifting the location of the perturbation domain strongly affected the amount of additional (excess) atmospheric $\mathrm{CO}_{2}$ simulated across these three sites. This is illustrated by the box and whisker plots in Fig. 3, which compare the aggregated sensitivities of all three sites to the central, northwest and southwest flux anomalies (prototypical will be discussed later). The central perturbation was better detected across all stations due to a greater overlap between station footprints and the central perturbation domain (Fig. A6). Furthermore, these stations lie along the same latitudinal band as the central perturbation domain, across which zonal transport dominates. The significance of perturbation location can be seen in Fig. 3 across increasing perturbation area where even an increase in perturbation area of eight times $\left(3.5^{\circ} \times 3.5^{\circ}\right.$ to $\left.10^{\circ} \times 10^{\circ}\right)$ for the northwest or southwest perturbations still yielded less excess $\mathrm{CO}_{2}$ than the smallest central perturbation $\left(3.5^{\circ} \times 3.5^{\circ}\right)$. Perturbations domains that do not overlap measurement stations do not strongly influence excess $\mathrm{CO}_{2}$. This is tempered somewhat by the apparent, though unsurprising, observation that when a perturbation domain overlaps a measurement station doubling the perturbation area yielded a less than double effect on excess $\mathrm{CO}_{2}$. For example in Fig. 3, each doubling in area of the central perturbation (e.g., $5^{\circ} \times 5^{\circ}$ to $7^{\circ} \times 7^{\circ}$ to $\left.10^{\circ} \times 10^{\circ}\right)$ resulted in less than a doubling of excess $\mathrm{CO}_{2}$. The same patterns in excess $\mathrm{CO}_{2}$ among stations occurs in the 3-hourly data pictured in Fig. A11 with the 
Biogeosciences Discuss., doi:10.5194/bg-2016-223, 2016

Manuscript under review for journal Biogeosciences

Published: 20 June 2016

(c) Author(s) 2016. CC-BY 3.0 License.

notable difference that the magnitude by which excess $\mathrm{CO}_{2}$ exceeds the measurement (intercompatibility) threshold can be much larger.

As opposed to the results from uniform flux anomalies, excess $\mathrm{CO}_{2}$ from the drought period (April, May, June) of the spatio-temporally varying prototypical drought is shown in the rightmost boxplot inset in Fig. 3. When aggregated across the three stations the prototypical drought appears weaker than even the smallest central perturbation. There are two reasons for this. First, the prototypical drought perimeter was generally situated more over HDP's footprint (Fig. A7) than the other two stations, which strongly hampered coherent detection by all three. Second, the prototypical drought occurred across late spring and early summer, rather than throughout the entire year, as was the case for the uniform flux anomalies. This particular period, although ecologically critical to carbon uptake in the Mountain West (Monson et al., 2005; Moore et al., 2008), happens also to coincide with seasonal changes that amount to reduced site sensitivity to flux anomalies within these prescribed domains (see also Fig. 4, which shows seasonality in excess $\mathrm{CO}_{2}$ despite a constant flux perturbation).

The geographical position of each $\mathrm{CO}_{2}$ measurement site was also particularly relevant for detection. Each site has a unique physiographic setting with particular airflow patterns and sensitivities to the surrounding landscape. Differences in amplitude of excess $\mathrm{CO}_{2}$ between stations in Fig. 4a-c reflect differences in sensitivity of those locations to the same flux anomaly. With respect to the central perturbation, SPL revealed the largest amplitude in excess $\mathrm{CO}_{2}$ as well as the best signal detection (relative to its site-specific detection threshold). SPL's monthly mean excess $\mathrm{CO}_{2}$ values exceeded its MDM detection threshold even at the smallest perturbation scale $\left(3.5^{\circ} \times 3.5^{\circ}\right.$, see Fig. A10c). NWR did not show significant detectability of the central perturbation until the $5^{\circ} \times 5^{\circ}$ scale largely due to its higher MDM detection threshold (Fig. A9b). HDP, despite having the lowest MDM uncertainty, did not register significant detectability of any perturbation until the $10^{\circ} \times 10^{\circ}$ perturbations scale, which can be attributed to the station's far-western location and limited overlap of footprint and perturbation domains (Figs. A5, A6).

\subsection{Quantifying detection of perturbations based on excess $\mathrm{CO}_{2}$}

These three mountaintop $\mathrm{CO}_{2}$ stations do indeed have different sensitivities to $\mathrm{CO}_{2}$ flux perturbations. While at first glance, this is not surprising, the results do reveal a remarkable level of variability that reflects the fact that transport is not random and site influence to fluxes decreases rapidly with distance (Fig. A6). Time series for each site appear in Fig. 4, and represent the monthly means of excess $\mathrm{CO}_{2}$ values from three (central, northwest, southwest) uniform flux perturbations at $10^{\circ} \mathrm{x} 10^{\circ}$ scale and a prototypical drought for the 2008 year (excess $\mathrm{CO}_{2}$ plots from the $7^{\circ} \times 7^{\circ}, 5^{\circ} \times 5^{\circ}$ and $3.5^{\circ} \times 3.5^{\circ}$ perturbations appear in Figs. A8-A10).

Across the three stations in Fig. 4 the excess $\mathrm{CO}_{2}$ signal was most consistent at HDP among shifting perturbation locations. This suggests that HDP could be the best positioned site for observing high magnitude, wide-spread disturbances throughout the Mountain West region, and was particularly sensitive to northwest and central perturbations. HDP was also best able to detect flux anomalies from the prototypical perturbation during May, well above the MDM detection threshold. NWR showed significant detection of the central perturbation (but not northwest or southwest), which was above the detection threshold for all months except April and May. Although SPL showed the strongest detection of the central perturbation, the other perturbation locations (northwest, southwest, prototypical) were not significantly detected. This was also the case for NWR. 
Biogeosciences Discuss., doi:10.5194/bg-2016-223, 2016

Manuscript under review for journal Biogeosciences

Published: 20 June 2016

(c) Author(s) 2016. CC-BY 3.0 License.

Seasonal variations in detection are also apparent in Fig. 4. Excess $\mathrm{CO}_{2}$ values for a given site differed by nearly a factor throughout the year. Peak values occurred during the non-summer months, while minima occurred from April through June, which coincides with the June through August peak in regional carbon uptake (Fig. 1 and see Sun et al., 2010). Since intensity of the uniform flux perturbations was equivalent throughout the year, any seasonal differences in detectability point to seasonally controlled atmospheric transport effects and thus sensitivity to upwind fluxes.

Shiga et al. (2014) examined seasonal sensitivities to fossil fuel emissions in North American in situ $\mathrm{CO}_{2}$ measurements. It was found that sensitivity attenuated during non-winter months due to compounding effects including biospheric fluxes, atmospheric transport-related errors, and reduced sensitivity of observations to underlying fluxes due to mixing in the planetary boundary layer. In our simulated experiments the detection thresholds do not consider confounding effects from biospheric fluxes or seasonal variability in atmospheric transport errors, thus the seasonal changes in detection at these three sites can only be attributed to seasonal differences in atmospheric transport, either enhancing or reducing detection of a signal from the locations where the droughts were imposed.

\subsection{Relevance of results and comparison to carbon balance estimates}

Climate extremes are now recognized to be a key process of growing importance in the regulation of the global carbon budget

(Reichstein et al., 2013). Understanding the terrestrial biosphere's carbon sequestration potential in the face of changing climate and disturbance regimes requires empirical information about carbon balance responses. This underscores the need to determine the sensitivity of $\mathrm{CO}_{2}$ measurement stations to carbon cycle perturbations of known intensity, as we have examined in this study.

U.S. forests are the dominant sink with an estimated carbon sequestration capacity of $-14 \mathrm{TgC} \mathrm{mo}^{-1}$ (Zhu et al., 2010).

'What magnitude must a carbon cycle anomaly have in order to be detected by a Mountain West $\mathrm{CO}_{2}$ observing station?' We produced a data set of excess $\mathrm{CO}_{2}$ values for each experimental case to address this question. Here the total monthly magnitude (area times intensity) of the perturbation is compared against the $-14 \mathrm{TgC} \mathrm{mo}^{-1}$ sequestration rate. The monthly magnitudes of the uniform flux anomalies were $+0.7 \mathrm{TgC} \mathrm{mo}^{-1}\left(3.5^{\circ} \times 3.5^{\circ}\right),+1.5 \mathrm{TgC} \mathrm{mo}^{-1}\left(5^{\circ} \times 5^{\circ}\right),+3 \mathrm{TgC} \mathrm{mo}^{-1}\left(7^{\circ} \times 7^{\circ}\right)$, $+6 \mathrm{TgC} \mathrm{mo}^{-1}\left(10^{\circ} \times 10^{\circ}\right)$ and $+1.6 \mathrm{TgC} \mathrm{mo}^{-1}$ (prototypical). We estimate the magnitude of our $3.5^{\circ} \times 3.5^{\circ}$ to $10^{\circ} \times 10^{\circ}$ and prototypical perturbations to represent about $5 \%, 11 \%, 21 \%, 43 \%$ and $11 \%$ of the total monthly U.S. forest carbon sequestration capacity. On a per unit area basis the uniform flux anomaly resulted in an additional release to the atmosphere of 6.3 $\mathrm{gC} \mathrm{m}^{-2} \mathrm{mo}^{-1}$.

Excess $\mathrm{CO}_{2}$ values exceeded MDM detection thresholds at SPL for the central perturbation at the smallest scale, $3.5^{\circ} \mathrm{x} 3.5^{\circ}$ (i.e., $5 \%$ of U.S. forest sequestration capacity). At NWR site-specific MDM uncertainty was much higher, requiring a $5^{\circ} \mathrm{x} 5^{\circ}$ perturbation (11\% of U.S. forest sequestration capacity) in order to produce significant detection. HDP required the largest area central perturbation $\left(10^{\circ} \times 10^{\circ}, 43 \%\right.$ of U.S. forest sequestration capacity) before revealing significant detection.

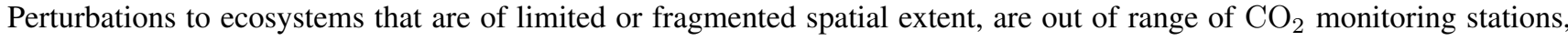
or cannot elicit carbon cycle perturbations of at least $3.5^{\circ} \mathrm{x} 3.5^{\circ}$ and $+0.2 \mu \mathrm{mol} \mathrm{C} \mathrm{m} \mathrm{s}^{-1}$ may not be well represented in the $\mathrm{CO}_{2}$ observations currently available for the U.S. Mountain West. Mountain pine beetle outbreaks resulting in mass lodgepole 
Biogeosciences Discuss., doi:10.5194/bg-2016-223, 2016

Manuscript under review for journal Biogeosciences

Published: 20 June 2016

(c) Author(s) 2016. CC-BY 3.0 License.

pine mortality and carbon release, could have a more varied spatial structure depending on the location of the trees, in a way not considered by this study. However future work could investigate such nuances by imposing a random flux field on top of the prototypical drought or perturbation with intensity approximating large scale tree mortality.

Pinning down ecosystems whose carbon balances are unstable or sensitive to exogenous change is critical to climate change 5 prediction efforts (Frank et al., 2015). Earth system models must accurately represent the sensitivities of ecosystems in order to realistically forecast changes in the terrestrial carbon balance. The work described here provides a useful sensitivity study of disturbance strength relative to uncertainty of observed atmospheric $\mathrm{CO}_{2}$.

\section{Conclusions}

This study evaluated the ability of atmospheric $\mathrm{CO}_{2}$ measurement stations in the U.S. Mountain West to detect moderate to extreme changes in the net carbon balance (5-43\% of U.S. forest carbon sequestration capacity). Location of the $\mathrm{CO}_{2}$ station relative to the perturbation perimeter is critical. At the smallest perturbation scales $\left(3.5^{\circ} \times 3.5^{\circ}\right)$ the uniform $+0.2 \mu \mathrm{mol} \mathrm{C} \mathrm{m}^{-2} \mathrm{~s}^{-1}$ flux anomaly was discernible above the model-data mismatch detection threshold consistently at SPL station (Fig. A10c) because it is positioned at the center of the perturbation domain (Fig. A5a), while the other two stations, positioned off-center or outside the perturbation perimeter, revealed much smaller excess $\mathrm{CO}_{2}$ values. By comparison, at $10^{\circ} \mathrm{x} 10^{\circ}$ scale the northwest and southwest perturbations (still with limited overlap, Fig. A5d) were overall less detectable by these three stations than the $3.5^{\circ} \times 3.5^{\circ}$ centrally located perturbation (Fig. A10 Cen vs. Fig. $4 \mathrm{NW}$, SW). The higher sensitivity to perturbations covering the central domain $\left(40^{\circ} \mathrm{N}\right)$ than those centered $5^{\circ}$ farther north or south was due to the dominance of zonal flow and overlap with station footprint perimeters.

Each station had a different sensitivity that was particular to its physiographic setting. Unsurprisingly, the amplitude in excess $\mathrm{CO}_{2}$ between stations was more equitable at larger perturbation domain sizes due to greater overlapping area between footprint and perturbation domain. This underscores the importance of incorporating suitable stations (e.g., Roof Butte Site, Arizona, http://raccoon.ucar.edu; Terra-PNW, http://terraweb.forestry.oregonstate.edu/research.htm) to enhance detection of less spatially pervasive droughts.

Despite constant intensity of the uniform flux anomaly, excess $\mathrm{CO}_{2}$ was found to vary throughout the year at these sites, which points to seasonal changes in atmospheric transport and thus sensitivity to upwind fluxes. Detectability was greatest during non-summer months, which implies that flux anomalies occurring during the growing season may not be as well represented in $\mathrm{CO}_{2}$ observations as anomalies that occur at other times of year. Note, however, that in this study we did not consider seasonal variability in atmospheric transport errors or confounding effects from biospheric fluxes, which could be used to develop seasonally adjusted detection thresholds, as opposed to the invariant ones used here.

Through this study we learned important qualitative rules for carbon cycle disturbance detection in the U.S. Mountain West in particular that: (1) seasonal differences in atmospheric transport favor detection of perturbations occurring during fall and winter significantly more than late spring and summer; and (2) although perturbations may be localized their impacts on atmospheric $\mathrm{CO}_{2}$ can be detected by nearby $\mathrm{CO}_{2}$ stations even without significantly affecting the annual carbon budget. An 
Biogeosciences Discuss., doi:10.5194/bg-2016-223, 2016

Manuscript under review for journal Biogeosciences

Published: 20 June 2016

(c) Author(s) 2016. CC-BY 3.0 License.

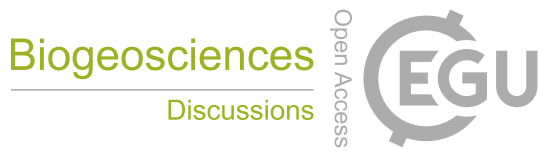

(c) (i)

elaboration of this approach, if applied to many more measurement sites, might provide a system for carbon cycle quantification of disturbances in net carbon fluxes in the future.

Acknowledgements. The authors thank Dong Hua who helped in the development of our analysis strategy. We are indebted to Ning Zeng and the VEGAS model group. We acknowledge MsTMIP data management support from the Modeling and Synthesis Thematic Data Center

5 at Oak Ridge National Laboratory (ORNL; http://nacp.ornl.gov). Funding for the Multi-scale synthesis and Terrestrial Model Intercomparison Project (MsTMIP; http://nacp.ornl.gov/MsTMIP.shtm) activity was provided through NASA ROSES Grant \#NNX10AG01A. Data management support for preparing, documenting, and distributing model driver and output data was performed by the Modeling and Synthesis Thematic Data Center at Oak Ridge National Laboratory (ORNL; http://nacp.ornl.gov), with funding through NASA ROSES Grant \#NNH10AN681. Finalized MsTMIP data products are archived at the ORNL DAAC (http://daac.ornl.gov). CarbonTracker CT2013 results provided by NOAA ESRL, Boulder, Colorado, USA from the website at http://carbontracker.noaa.gov. For contributions to our WRF-STILT simulation data we also thank Janusz Eluszkiewicz, Thomas Nehrkorn, and John Henderson from Atmospheric and Environmental Research, Inc., and also Michael Trudeau and Gabrielle Petron from NOAA ESRL/CIRES and Arlyn Andrews (NOAA ESRL). For editorial comments we thank William Christie, William Hargrove and Lars Pomara. We thank NOAA for supporting this work through NOAA CPO grant numbers NA09OAR4310065 and NA080AR4310533. We also thank the U.S. Department of Energy, which currently supports RACCOON

15 through grants DE-SC001625 and DE-SC0010624. The National Center for Atmospheric Research is sponsored by the National Science Foundation. 
Biogeosciences Discuss., doi:10.5194/bg-2016-223, 2016

Manuscript under review for journal Biogeosciences

Published: 20 June 2016

(c) Author(s) 2016. CC-BY 3.0 License.

\section{References}

Allen, C. D., Macalady, A. K., Chenchouni, H., Bachelet, D., McDowell, N., Vennetier, M., Kitzberger, T., Rigling, A., Breshears, D. D., Hogg, E. T., Gonzalez, P., Fensham, R., Zhang, Z., Castro, J., Demidova, N., Lim, J.-H., Allard, G., Running, S. W., Semerci, A., and Cobb, N.: A global overview of drought and heat-induced tree mortality reveals emerging climate change risks for forests, Forest Ecology and Management, 259, 660 - 684, doi:http://dx.doi.org/10.1016/j.foreco.2009.09.001, http://www.sciencedirect.com/science/article/ pii/S037811270900615X, adaptation of Forests and Forest Management to Changing Climate Selected papers from the conference on "Adaptation of Forests and Forest Management to Changing Climate with Emphasis on Forest Health: A Review of Science, Policies and Practices", Umeå, Sweden, August 25-28, 2008., 2010.

Bonan, G. B.: Forests and Climate Change: Forcings, Feedbacks, and the Climate Benefits of Forests, Science, 320, 1444-1449, doi:10.1126/science.1155121, http://www.sciencemag.org/content/320/5882/1444.abstract, 2008.

Brooks, B.-G. J., Desai, A. R., Stephens, B. B., Bowling, D. R., Burns, S. P., Watt, A. S., Heck, S. L., and Sweeney, C.: Assessing filtering of mountaintop $\mathrm{CO}_{2}$ mole fractions for application to inverse models of biosphere-atmosphere carbon exchange, Atmospheric Chemistry and Physics, 12, 2099-2115, doi:10.5194/acp-12-2099-2012, http://www.atmos-chem-phys.net/12/2099/2012/, 2012.

Chatterjee, A., Michalak, A. M., Anderson, J. L., Mueller, K. L., and Yadav, V.: Toward reliable ensemble Kalman filter estimates of CO2 fluxes, Journal of Geophysical Research: Atmospheres, 117, n/a-n/a, doi:10.1029/2012JD018176, http://dx.doi.org/10.1029/ 2012JD018176, d22306, 2012.

Ciais, P., Reichstein, M., Viovy, N., Granier, A., Ogee, J., Allard, V., Aubinet, M., Buchmann, N., Bernhofer, C., Carrara, A., Chevallier, F., De Noblet, N., Friend, A. D., Friedlingstein, P., Grunwald, T., Heinesch, B., Keronen, P., Knohl, A., Krinner, G., Loustau, D., Manca, G., Matteucci, G., Miglietta, F., Ourcival, J. M., Papale, D., Pilegaard, K., Rambal, S., Seufert, G., Soussana, J. F., Sanz, M. J., Schulze, E. D., Vesala, T., and Valentini, R.: Europe-wide reduction in primary productivity caused by the heat and drought in 2003 , Nature, 437 , doi:10.1038/nature03972, http://dx.doi.org/10.1038/nature03972, 2005.

Ciais, P., Rayner, P., Chevallier, F., Bousquet, P., Logan, M., Peylin, P., and Ramonet, M.: Atmospheric inversions for estimating CO2 fluxes: methods and perspectives, Climatic Change, 103, 69-92, doi:10.1007/s10584-010-9909-3, http://dx.doi.org/10.1007/s10584-010-9909-3, 2010.

Diffenbaugh, N. S. and Field, C. B.: Changes in Ecologically Critical Terrestrial Climate Conditions, Science, 341, 486-492, doi:10.1126/science.1237123, http://www.sciencemag.org/content/341/6145/486.abstract, 2013.

Frank, D., Reichstein, M., Bahn, M., Thonicke, K., Frank, D., Mahecha, M. D., Smith, P., van der Velde, M., Vicca, S., Babst, F., Beer, C., Buchmann, N., Canadell, J. G., Ciais, P., Cramer, W., Ibrom, A., Miglietta, F., Poulter, B., Rammig, A., Seneviratne, S. I., Walz, A., Wattenbach, M., Zavala, M. A., and Zscheischler, J.: Effects of climate extremes on the terrestrial carbon cycle: concepts, processes and potential future impacts, Global Change Biology, pp. n/a-n/a, doi:10.1111/gcb.12916, http://dx.doi.org/10.1111/gcb.12916, 2015.

Gatti, L. V., Gloor, M., Miller, J. B., Doughty, C. E., Malhi, Y., Domingues, L. G., Basso, L. S., Martinewski, A., Correia, C. S. C., Borges, V. F., Freitas, S., Braz, R., Anderson, L. O., Rocha, H., Grace, J., Phillips, O. L., and Lloyd, J.: Drought sensitivity of Amazonian carbon balance revealed by atmospheric measurements, Nature, 506, doi:10.1038/nature12957, http://dx.doi.org/10.1038/nature12957, 2014.

Gibbs, H. K.: Olson's major world ecosystem complexes ranked by carbon in live vegetation: an updated database using the GLC2000 land cover product, http://cdiac.ornl.gov/epubs/ndp/ndp017/ndp017b.html, http://cdiac.ornl.gov/epubs/ndp/ndp017/ndp017b.html, carbon Dioxide Information Center, Oak Ridge National Laboratory, Oak Ridge, TN, 2006. 
Biogeosciences Discuss., doi:10.5194/bg-2016-223, 2016

Manuscript under review for journal Biogeosciences

Published: 20 June 2016

(c) Author(s) 2016. CC-BY 3.0 License.

Göckede, M., Markkanen, T., Hasager, C. B., and Foken, T.: Update of a Footprint-Based Approach for the Characterisation of Complex Measurement Sites, Boundary-Layer Meteorology, 118, 635-655, doi:10.1007/s10546-005-6435-3, http://dx.doi.org/10.1007/ s10546-005-6435-3, 2006.

Harte, J., Saleska, S., and Shih, T.: Shifts in plant dominance control carbon-cycle responses to experimental warming and widespread drought, Environmental Research Letters, 1, 014 001, http://stacks.iop.org/1748-9326/1/i=1/a=014001, 2006.

Hayes, D. J., Turner, D. P., Stinson, G., McGuire, A. D., Wei, Y., West, T. O., Heath, L. S., de Jong, B., McConkey, B. G., Birdsey, R. A., Kurz, W. A., Jacobson, A. R., Huntzinger, D. N., Pan, Y., Post, W. M., and Cook, R. B.: Reconciling estimates of the contemporary North American carbon balance among terrestrial biosphere models, atmospheric inversions, and a new approach for estimating net ecosystem exchange from inventory-based data, Global Change Biology, 18, 1282-1299, doi:10.1111/j.1365-2486.2011.02627.x, http: //dx.doi.org/10.1111/j.1365-2486.2011.02627.x, 2012.

Hicke, J. A., Allen, C. D., Desai, A. R., Dietze, M. C., Hall, R. J., (Ted) Hogg, E. H., Kashian, D. M., Moore, D., Raffa, K. F., Sturrock, R. N., and Vogelmann, J.: Effects of biotic disturbances on forest carbon cycling in the United States and Canada, Global Change Biology, 18, 7-34, doi:10.1111/j.1365-2486.2011.02543.x, http://dx.doi.org/10.1111/j.1365-2486.2011.02543.x, 2012.

Hu, J., Moore, D. J. P., Burns, S. P., and Monson, R. K.: Longer growing seasons lead to less carbon sequestration by a subalpine forest, Global Change Biology, 16, 771-783, doi:10.1111/j.1365-2486.2009.01967.x, http://dx.doi.org/10.1111/j.1365-2486.2009.01967.x, 2010.

Huntzinger, D. N., Schwalm, C., Michalak, A. M., Schaefer, K., King, A. W., Wei, Y., Jacobson, A., Liu, S., Cook, R. B., Post, W. M., Berthier, G., Hayes, D., Huang, M., Ito, A., Lei, H., Lu, C., Mao, J., Peng, C. H., Peng, S., Poulter, B., Riccuito, D., Shi, X., Tian, H., Wang, W., Zeng, N., Zhao, F., and Zhu, Q.: The North American Carbon Program Multi-Scale Synthesis and Terrestrial Model Intercomparison Project â€“ Part 1: Overview and experimental design, Geoscientific Model Development, 6, 2121-2133, doi:10.5194/gmd-6-2121-2013, http://www.geosci-model-dev.net/6/2121/2013/, 2013.

Jolly, W. M., Cochrane, M. A., Freeborn, P. H., Holden, Z. A., Brown, T. J., Williamson, G. J., and Bowman, D. M. J. S.: Climate-induced variations in global wildfire danger from 1979 to 2013, Nature Communications, 6, doi:10.1038/ncomms8537, http://dx.doi.org/10.1038/ ncomms8537, 2015.

Lauvaux, T., Pannekoucke, O., Sarrat, C., Chevallier, F., Ciais, P., Noilhan, J., and Rayner, P. J.: Structure of the transport uncertainty in mesoscale inversions of CO2 sources and sinks using ensemble model simulations, Biogeosciences, 6, 1089-1102, doi:10.5194/bg-61089-2009, http://dx.doi.org/10.5194/bg-6-1089-2009, 2009.

Le Quéré, C., Andres, R. J., Boden, T., Conway, T., Houghton, R. A., House, J. I., Marland, G., Peters, G. P., van der Werf, G. R., Ahlström, A., Andrew, R. M., Bopp, L., Canadell, J. G., Ciais, P., Doney, S. C., Enright, C., Friedlingstein, P., Huntingford, C., Jain, A. K., Jourdain, C., Kato, E., Keeling, R. F., Klein Goldewijk, K., Levis, S., Levy, P., Lomas, M., Poulter, B., Raupach, M. R., Schwinger, J., Sitch, S., Stocker, B. D., Viovy, N., Zaehle, S., and Zeng, N.: The global carbon budget 1959â€“'2011, Earth System Science Data, 5, 165-185, doi:10.5194/essd-5-165-2013, http://www.earth-syst-sci-data.net/5/165/2013/, 2013.

Lin, J. C., Gerbig, C., Wofsy, S. C., Andrews, A. E., Daube, B. C., Davis, K. J., and Grainger, C. A.: A near-field tool for simulating the upstream influence of atmospheric observations: The Stochastic Time-Inverted Lagrangian Transport (STILT) model, Journal of Geophysical Research: Atmospheres, 108, n/a-n/a, doi:10.1029/2002JD003161, http://dx.doi.org/10.1029/2002JD003161, $4493,2003$.

Martínez-Vilalta, J., Lloret, F., and Breshears, D. D.: Drought-induced forest decline: causes, scope and implications, Biology Letters, 8, 689-691, doi:10.1098/rsbl.2011.1059, 2012.

Monson, R., Sparks, J., Rosenstiel, T., Scott-Denton, L., Huxman, T., Harley, P., Turnipseed, A., Burns, S., Backlund, B., and Hu, J.: Climatic influences on net ecosystem $\mathrm{CO} 2$ exchange during the transition from wintertime carbon source to springtime carbon sink in a high- 
Biogeosciences Discuss., doi:10.5194/bg-2016-223, 2016

Manuscript under review for journal Biogeosciences

Published: 20 June 2016

(c) Author(s) 2016. CC-BY 3.0 License.

elevation, subalpine forest, Oecologia, 146, 130-147, doi:10.1007/s00442-005-0169-2, http://dx.doi.org/10.1007/s00442-005-0169-2, 2005.

Moore, D. J., Hu, J., Sacks, W. J., Schimel, D. S., and Monson, R. K.: Estimating transpiration and the sensitivity of carbon uptake to water availability in a subalpine forest using a simple ecosystem process model informed by measured net CO 2 and $\mathrm{H} 2 \mathrm{O}$ fluxes, Agricultural and Forest Meteorology, 148, 1467-1477, 2008.

Nehrkorn, T., Eluszkiewicz, J., Wofsy, S., Lin, J., Gerbig, C., Longo, M., and Freitas, S.: Coupled weather research and forecasting-stochastic time-inverted lagrangian transport (WRF-STILT) model, Meteorology and Atmospheric Physics, 107, 51-64, doi:10.1007/s00703-0100068-x, http://dx.doi.org/10.1007/s00703-010-0068-x, 2010.

Pan, Y., Birdsey, R. A., Fang, J., Houghton, R., Kauppi, P. E., Kurz, W. A., Phillips, O. L., Shvidenko, A., Lewis, S. L., Canadell, J. G., Ciais, P., Jackson, R. B., Pacala, S. W., McGuire, A. D., Piao, S., Rautiainen, A., Sitch, S., and Hayes, D.: A Large and Persistent Carbon Sink in the World's Forests, Science, 333, 988-993, doi:10.1126/science.1201609, http://www.sciencemag.org/content/333/6045/988.abstract, 2011.

Peters, W., Jacobson, A. R., Sweeney, C., Andrews, A. E., Conway, T. J., Masarie, K., Miller, J. B., Bruhwiler, L. M. P., Pétron, G., Hirsch, A. I., Worthy, D. E. J., van der Werf, G. R., Randerson, J. T., Wennberg, P. O., Krol, M. C., and Tans, P. P.: An atmospheric perspective on North American carbon dioxide exchange: CarbonTracker, Proceedings of the National Academy of Sciences, 104, 18925-18 930, doi:10.1073/pnas.0708986104, http://www.pnas.org/content/104/48/18925.abstract, 2007.

Peters, W., Krol, M. C., Van Der Werf, G. R., Houweling, S., Jones, C. D., Hughes, J., Schaefer, K., Masarie, K. A., Jacobson, A. R., Miller, J. B., Cho, C. H., Ramonet, M., Schmidt, M., Ciattaglia, L., Apadula, F., Heltai, D., Meinhardt, F., Di Sarra, A. G., Piacentino, S., Sferlazzo, D., Aalto, T., Hatakka, J., Ström, J., Haszpra, L., Meijer, H. A. J., Van der Laan, S., Neubert, R. E. M., Jordan, A., Rodó, X., Morguí, J.-A., Vermeulen, A. T., Popa, E., Rozanski, K., Zimnoch, M., Manning, A. C., Leuenberger, M., Uglietti, C., Dolman, A. J., Ciais, P., Heimann, M., and Tans, P. P.: Seven years of recent European net terrestrial carbon dioxide exchange constrained by atmospheric observations, Global Change Biology, 16, 1317-1337, doi:10.1111/j.1365-2486.2009.02078.x, http://dx.doi.org/10.1111/j. 1365-2486.2009.02078.x, 2010.

Reichstein, M., Bahn, M., Ciais, P., Frank, D., Mahecha, M. D., Seneviratne, S. I., Zscheischler, J., Beer, C., Buchmann, N., Frank, D. C., Papale, D., Rammig, A., Smith, P., Thonicke, K., van der Velde, M., Vicca, S., Walz, A., and Wattenbach, M.: Climate extremes and the carbon cycle, Nature, 500, 287-295, doi:10.1038/nature12350, http://dx.doi.org/10.1038/nature12350, 2013.

Shiga, Y. P., Michalak, A. M., Randolph Kawa, S., and Engelen, R. J.: In-situ CO2 monitoring network evaluation and design: A criterion based on atmospheric CO2 variability, Journal of Geophysical Research: Atmospheres, 118, 2007-2018, doi:10.1002/jgrd.50168, http: //dx.doi.org/10.1002/jgrd.50168, 2013.

Shiga, Y. P., Michalak, A. M., Gourdji, S. M., Mueller, K. L., and Yadav, V.: Detecting fossil fuel emissions patterns from subcontinental regions using North American in situ CO2 measurements, Geophysical research letters, 41, 4381-4388, 2014.

Stephens, B. B., Watt, A., and Maclean, G.: An autonomous inexpensive robust $\mathrm{CO}_{2}$ analyzer (AIRCOA), in: 13th WMO/IAEA Meeting of Experts on Carbon Dioxide Concentration and Related Tracers Measurement Techniques, WMO TD, vol. 1359, pp. 95-99, 2006.

Stephens, B. B., Miles, N. L., Richardson, S. J., Watt, A. S., and Davis, K. J.: Atmospheric $\mathrm{CO}_{2}$ monitoring with single-cell NDIR-based analyzers, Atmospheric Measurement Techniques, 4, 2737-2748, doi:10.5194/amt-4-2737-2011, http://www.atmos-meas-tech.net/4/2737/ 2011/, 2011. 
Biogeosciences Discuss., doi:10.5194/bg-2016-223, 2016

Manuscript under review for journal Biogeosciences

Published: 20 June 2016

(c) Author(s) 2016. CC-BY 3.0 License.

Sun, J., Oncley, S. P., Burns, S. P., Stephens, B. B., Lenschow, D. H., Campos, T., Watt, A. S., Monson, R. K., Moore, D. J., Hu, J., et al.: A multiscale and multidisciplinary investigation of ecosystem-atmosphere CO2 exchange over the Rocky Mountains of Colorado, Bulletin of the American Meteorological Society, 91, 209-230, 2010.

van der Molen, M., Dolman, A., Ciais, P., Eglin, T., Gobron, N., Law, B., Meir, P., Peters, W., Phillips, O., Reichstein, M., Chen, T., Dekker, S., Doubková, M., Friedl, M., Jung, M., van den Hurk, B., de Jeu, R., Kruijt, B., Ohta, T., Rebel, K., Plummer, S., Seneviratne, S., Sitch, S., Teuling, A., van der Werf, G., and Wang, G.: Drought and ecosystem carbon cycling, Agricultural and Forest Meteorology, 151, 765 773, doi:http://dx.doi.org/10.1016/j.agrformet.2011.01.018, http://www.sciencedirect.com/science/article/pii/S0168192311000517, 2011. van Mantgem, P. J., Stephenson, N. L., Byrne, J. C., Daniels, L. D., Franklin, J. F., Fulé, P. Z., Harmon, M. E., Larson, A. J., Smith, J. M., Taylor, A. H., and Veblen, T. T.: Widespread Increase of Tree Mortality Rates in the Western United States, Science, 323, 521-524, doi:10.1126/science.1165000, http://www.sciencemag.org/content/323/5913/521.abstract, 2009.

Walter, J., Jentsch, A., Beierkuhnlein, C., and Kreyling, J.: Ecological stress memory and cross stress tolerance in plants in the face of climate extremes, Environmental and Experimental Botany, 94, 3-8, doi:http://dx.doi.org/10.1016/j.envexpbot.2012.02.009, http://www. sciencedirect.com/science/article/pii/S0098847212000482, cross-stress tolerance and stress "memory" in plants, 2013.

Wang, X., Piao, S., Ciais, P., Friedlingstein, P., Myneni, R. B., Cox, P., Heimann, M., Miller, J., Peng, S., Wang, T., Yang, H., and Chen, A.: A two-fold increase of carbon cycle sensitivity to tropical temperature variations, Nature, 506, doi:10.1038/nature12915, http://dx.doi. org/10.1038/nature12915, 2014.

Zeng, N.: Glacial-interglacial atmospheric CO2 change -The glacial burial hypothesis, Advances in Atmospheric Sciences, 20, 677-693, doi:10.1007/BF02915395, http://dx.doi.org/10.1007/BF02915395, 2003.

Zeng, N., Qian, H., Munoz, E., and Iacono, R.: How strong is carbon cycle-climate feedback under global warming?, Geophysical Research Letters, 31, n/a-n/a, doi:10.1029/2004GL020904, http://dx.doi.org/10.1029/2004GL020904, 120203, 2004.

Zeng, N., Mariotti, A., and Wetzel, P.: Terrestrial mechanisms of interannual CO2 variability, Global Biogeochemical Cycles, 19, n/a-n/a, doi:10.1029/2004GB002273, http://dx.doi.org/10.1029/2004GB002273, gB1016, 2005.

Zhu, Z., Bergamaschi, B., Bernknopf, R., Clow, D., Dye, D., Faulkner, S., Forney, W., Gleason, R., Hawbaker, T., Liu, J., Liu, S., Prisley, S., Reed, B., Reeves, M., Rollins, M., Sleeter, B., Sohl, T., Stackpoole, S., Stehman, S., Striegl, R., Wein, A., and Zhu, Z.: A method for assessing carbon stocks, carbon sequestration, and greenhouse-gas fluxes in ecosystems of the United States under present conditions and future scenarios, http://pubs.usgs.gov/sir/2010/5233/, u.S. Geological Survey Scientific Investigations, Report 2010-5233, 2010.

Zscheischler, J., Mahecha, M. D., Harmeling, S., and Reichstein, M.: Detection and attribution of large spatiotemporal extreme events in Earth observation data, Ecological Informatics, 15, 66 - 73, doi:http://dx.doi.org/10.1016/j.ecoinf.2013.03.004, http://www.sciencedirect. com/science/article/pii/S1574954113000253, 2013.

Zscheischler, J., Michalak, A. M., Schwalm, C., Mahecha, M. D., Huntzinger, D. N., Reichstein, M., Berthier, G., Ciais, P., Cook, R. B., El-Masri, B., Huang, M., Ito, A., Jain, A., King, A., Lei, H., Lu, C., Mao, J., Peng, S., Poulter, B., Ricciuto, D., Shi, X., Tao, B., Tian, H., Viovy, N., Wang, W., Wei, Y., Yang, J., and Zeng, N.: Impact of large-scale climate extremes on biospheric carbon fluxes: An intercomparison based on MsTMIP data, Global Biogeochemical Cycles, 28, 585-600, doi:10.1002/2014GB004826, http://dx.doi.org/10. 1002/2014GB004826, 2014. 
Biogeosciences Discuss., doi:10.5194/bg-2016-223, 2016

Manuscript under review for journal Biogeosciences

Published: 20 June 2016

(c) Author(s) 2016. CC-BY 3.0 License.

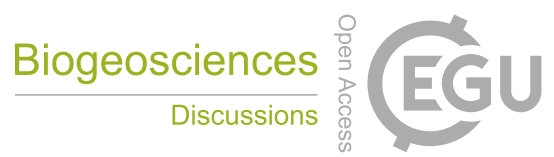

(c) (i)

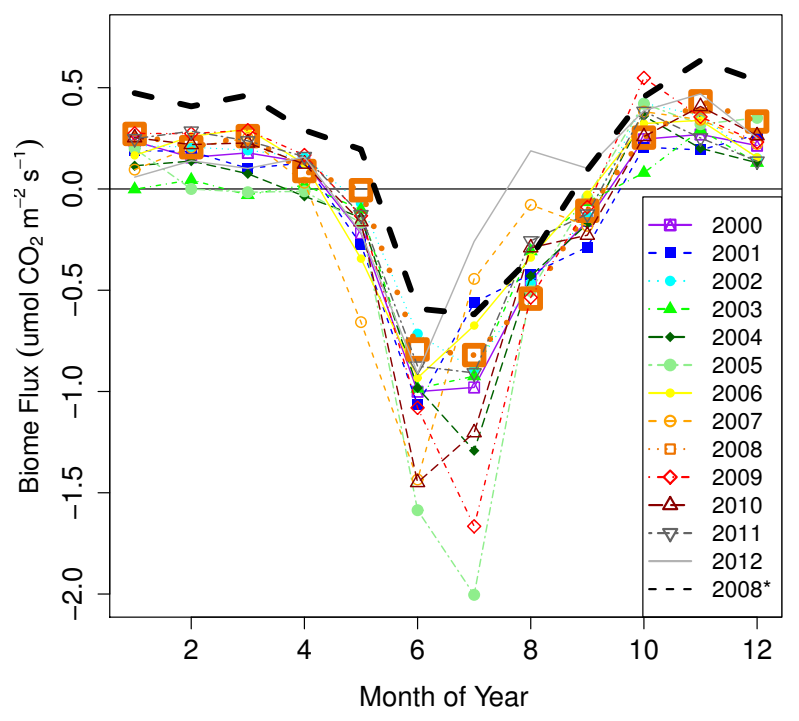

Figure 1. Biospheric carbon exchange by year from CT2013. Monthly mean C-flux averaged over the Mountain West domain (approx. $35^{\circ}-50^{\circ} \mathrm{N}, 100^{\circ}-115^{\circ} \mathrm{W}$ ) is plotted as a function of month of year. Carbon flow from the atmosphere to biosphere (uptake) is indicated by negative values. 2008 is our test year and for sensitivity experiments we compared the original 2008 data (red line) against a perturbed analogue (2008*, black dashed line) for which each 2008 flux estimate is incremented by an amount $\left(+0.2 \mu \mathrm{mol} \mathrm{C} \mathrm{m}^{-2} \mathrm{~s}^{-1}\right)$ equal to the total difference in annual means across all CarbonTracker years (2000-2010). 
Biogeosciences Discuss., doi:10.5194/bg-2016-223, 2016

Manuscript under review for journal Biogeosciences

Published: 20 June 2016

(c) Author(s) 2016. CC-BY 3.0 License.

(c) (i)

(a) $\mathrm{NWR} \mathrm{CO}_{2}, 12 / 07 / 2008$ 08:00LT -36hrs ppm

(b) $\mathrm{NWR} \mathrm{CO}_{2}, 12 / 07 / 2008$ 08:00LT -35hrs ppm
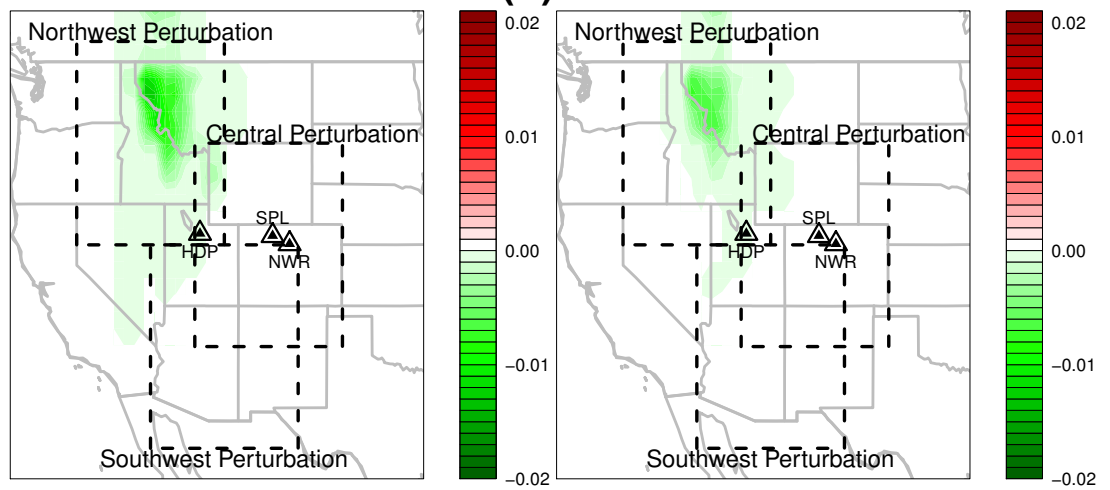

(c)

$\mathrm{NWR} \mathrm{CO}_{2}$, 12/07/2008 08:00LT -34hrs ppm (d)

dWR $\mathrm{CO}_{2}, 12 / 07 / 2008$ 08:00LT -33hrs ppm
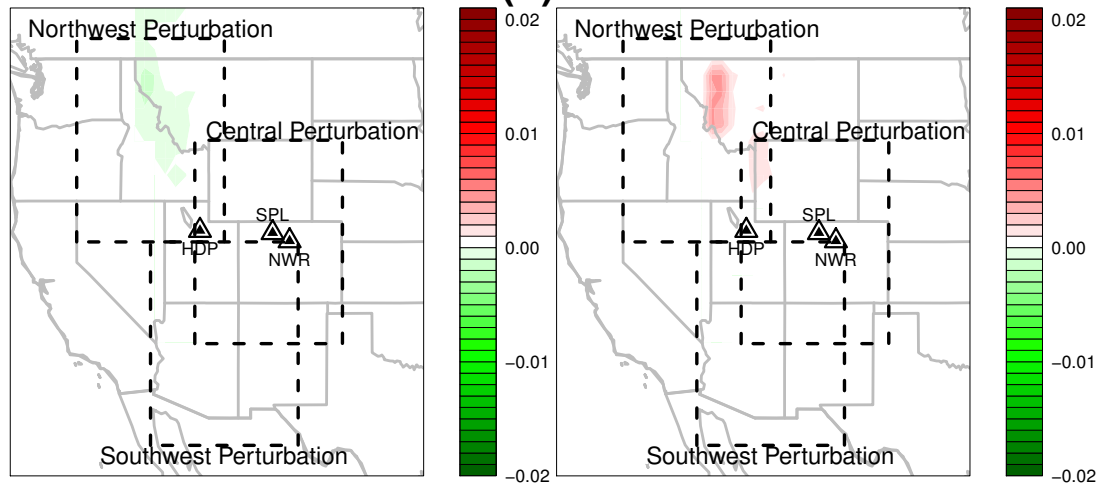

Figure 2. Upwind gridded $\left(1^{\circ} \mathrm{x} 1^{\circ}\right) \mathrm{CO}_{2}$-excess values for NWR station at 08:00 LT determined by convolving WRF-STILT with CT2013. Boxes indicate the $10^{\circ} \times 10^{\circ}$ perturbation domains. These plots reveal the location and contribution of upwind sources to simulated $\mathrm{CO}_{2}$ at NWR. Ecosystem sources contributing air relatively depleted in $\mathrm{CO}_{2}$ appear green, while sources contributing $\mathrm{CO}_{2}$ enriched air appear red. These snapshots (a-d) represent fluxes at 36-33 hours prior that influenced $\mathrm{CO}_{2}$ at NWR at 08:00 LT. 
Biogeosciences Discuss., doi:10.5194/bg-2016-223, 2016

Manuscript under review for journal Biogeosciences

Published: 20 June 2016

(c) Author(s) 2016. CC-BY 3.0 License.

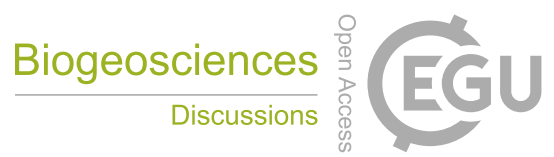

(c) (i)

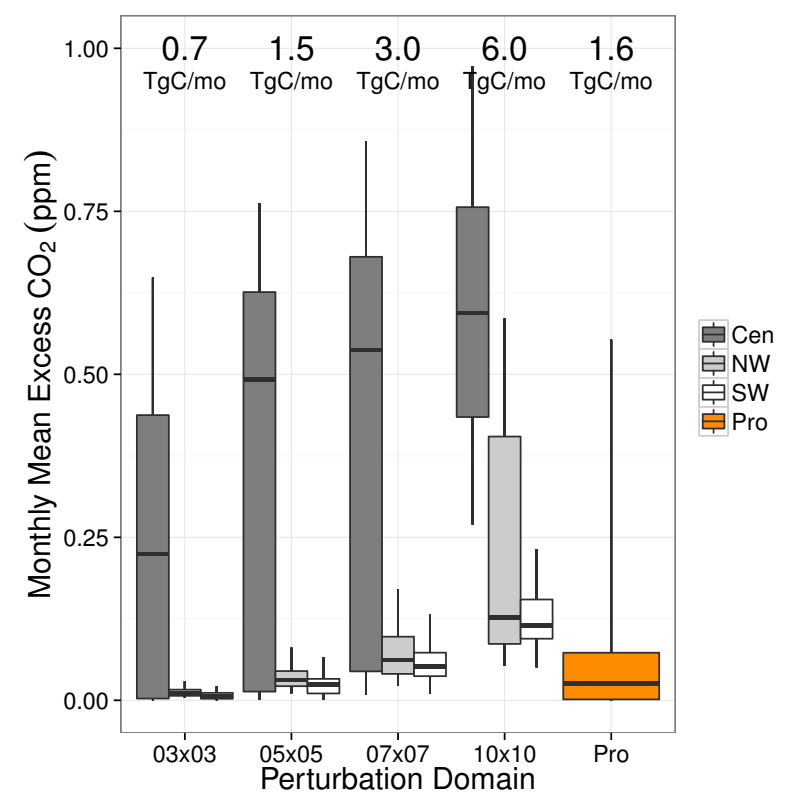

Figure 3. Combined (3 stations) monthly excess $\mathrm{CO}_{2}$ by perturbation size and perturbation location. Box and whisker quantiles from monthly mean excess $\mathrm{CO}_{2}$ values from the three $\mathrm{CO}_{2}$ stations are shown for differently positioned perturbations. Each box and whisker for Cen, NW, and SW represent data points from 12 monthly means $x 3$ sites, while Pro represents 3 months $\mathrm{x} 3$ sites. The change in excess $\mathrm{CO}_{2}$ with increasing perturbation area is shown from left to right, except prototypical, which has an area of approximately equivalent to $5^{\circ} \times 5^{\circ}$. Perturbation magnitude, as monthly mean from the annual total, is shown for each perturbation size across the top. 
Biogeosciences Discuss., doi:10.5194/bg-2016-223, 2016

Manuscript under review for journal Biogeosciences

Published: 20 June 2016

(c) Author(s) 2016. CC-BY 3.0 License.

\section{(c) ${ }_{\mathrm{By}}$}

(a) HDP Detection of $10 \times 10$ \& Prototypical

(b) NWR Detection of $10 \times 10$ \& Prototypical
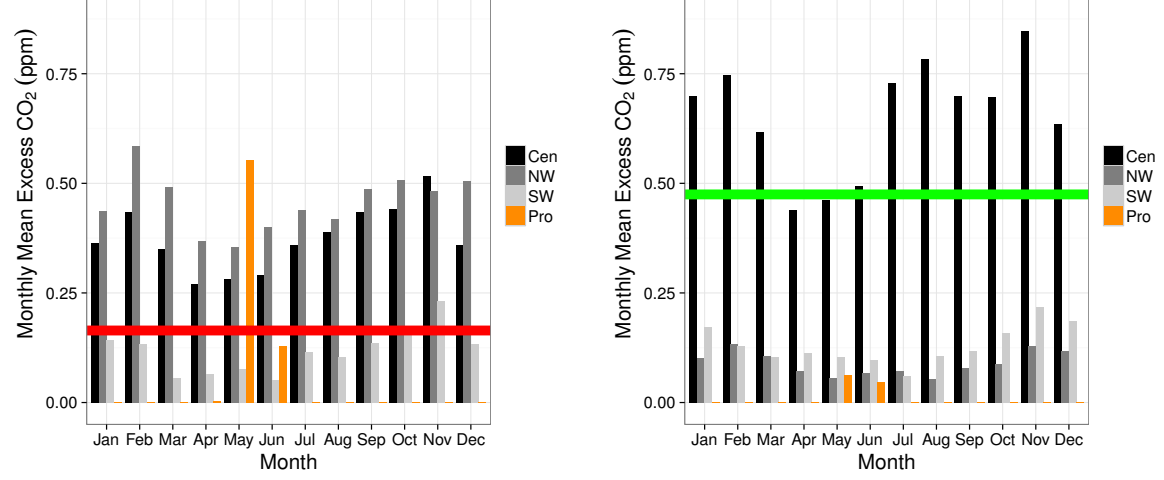

(c) SPL Detection of $10 \times 10$ \& Prototypical

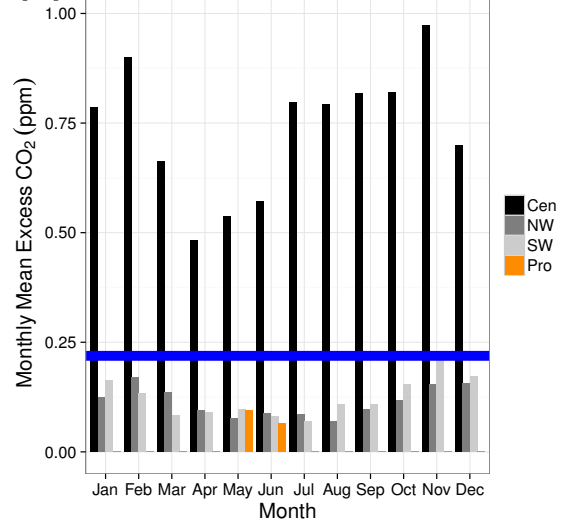

Figure 4. Monthly mean excess $\mathrm{CO}_{2}$ values for the $10^{\circ} \times 10^{\circ}$ and prototypical perturbations are indicated by the height of the vertical bars. Figure panels a-c distinguish the three measurement stations HDP, NWR, and SPL respectively. Perturbation cases (central, northwest, southwest, prototypical) are distinguished by color. Station-specific $\sigma / \sqrt{\mathrm{n}}$ values are used as detection thresholds derived from MDM error variances (Shiga et al., 2014, see Section 2.7). 
Biogeosciences Discuss., doi:10.5194/bg-2016-223, 2016

Manuscript under review for journal Biogeosciences

Published: 20 June 2016

(c) Author(s) 2016. CC-BY 3.0 License.

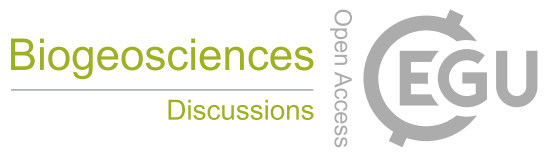

(c) (i)

Table 1. Mean annual carbon flux for the U.S. Mountain West from CT2013. This provides a profile of comparison for our study year (2008) and the uniform flux perturbation case $(2008 *)$

\begin{tabular}{cc}
\hline & \multicolumn{2}{c}{ Mean annual } \\
& \multicolumn{2}{c}{ C flux } \\
Year & $\left(\mu \mathrm{mol} \mathrm{C} \mathrm{m}{ }^{-2} \mathrm{~s}^{-1}\right)$ \\
\hline 2000 & -0.103 \\
2001 & -0.098 \\
2002 & -0.043 \\
2003 & -0.170 \\
2004 & -0.120 \\
2005 & -0.225 \\
2006 & -0.023 \\
2007 & -0.101 \\
2008 & -0.036 \\
2009 & -0.083 \\
2010 & -0.161 \\
\hline $2008 *$ & 0.164 \\
\hline
\end{tabular}

Note that $2008^{*}$, the perturbation case,

is adjusted toward carbon-release by

$+0.2 \mu \mathrm{mol} \mathrm{C} \mathrm{m}{ }^{-2} \mathrm{~s}^{-1}$, our nominal

flux anomaly, which represents the range

of all the annual means above.

Table 2. $1 \sigma$ model-data mismatch values from 1 year of 3 hourly averages (see supporting information ts01.xlsx in Shiga et al., 2014) from which we derive our detection thresholds. To account for imperfect atmospheric transport in the model, we use the more stringent assumption that each day (not each 3-hourly average) is independent. Thus we use detection thresholds that are standard errors for the larger (longer) sampling period calculated parsimoniously as $\sigma / \mathrm{n}$, where $\mathrm{n}=30$.

\begin{tabular}{lrc}
\hline & \multicolumn{1}{c}{$\sigma$} & $\sigma / \sqrt{\mathrm{n}}$ \\
Site & $(\mathrm{ppm})$ & $(\mathrm{ppm})$ \\
\hline HDP & 0.9 & 0.16 \\
NWR & 2.6 & 0.47 \\
SPL & 1.2 & 0.22 \\
\hline
\end{tabular}


Biogeosciences Discuss., doi:10.5194/bg-2016-223, 2016

Manuscript under review for journal Biogeosciences

Published: 20 June 2016

(c) Author(s) 2016. CC-BY 3.0 License.

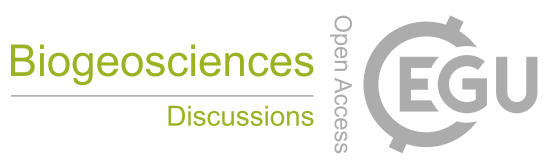

(c) (i)

\section{Data and code availability}

Data files containing the biospheric fluxes from CarbonTracker, influence functions from WRF-STILT, as well as R code used for convolution and generating our plots are freely available upon email request (bjorn@ geobabble.org). These data are 3.6 GB in size and will be downloadable via ftp server. 
Biogeosciences Discuss., doi:10.5194/bg-2016-223, 2016

Manuscript under review for journal Biogeosciences

Published: 20 June 2016

(c) Author(s) 2016. CC-BY 3.0 License.

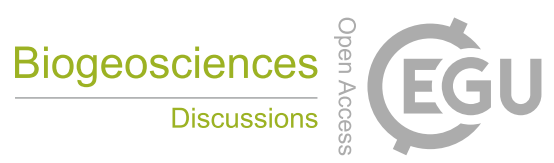

(c) (i)

Appendix A: Supplementary figures 
Biogeosciences Discuss., doi:10.5194/bg-2016-223, 2016

Manuscript under review for journal Biogeosciences

Published: 20 June 2016

(c) Author(s) 2016. CC-BY 3.0 License.

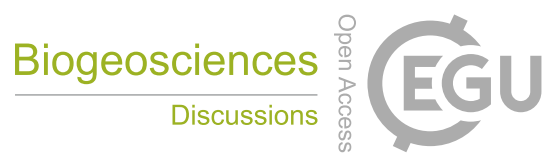

(c) (1)
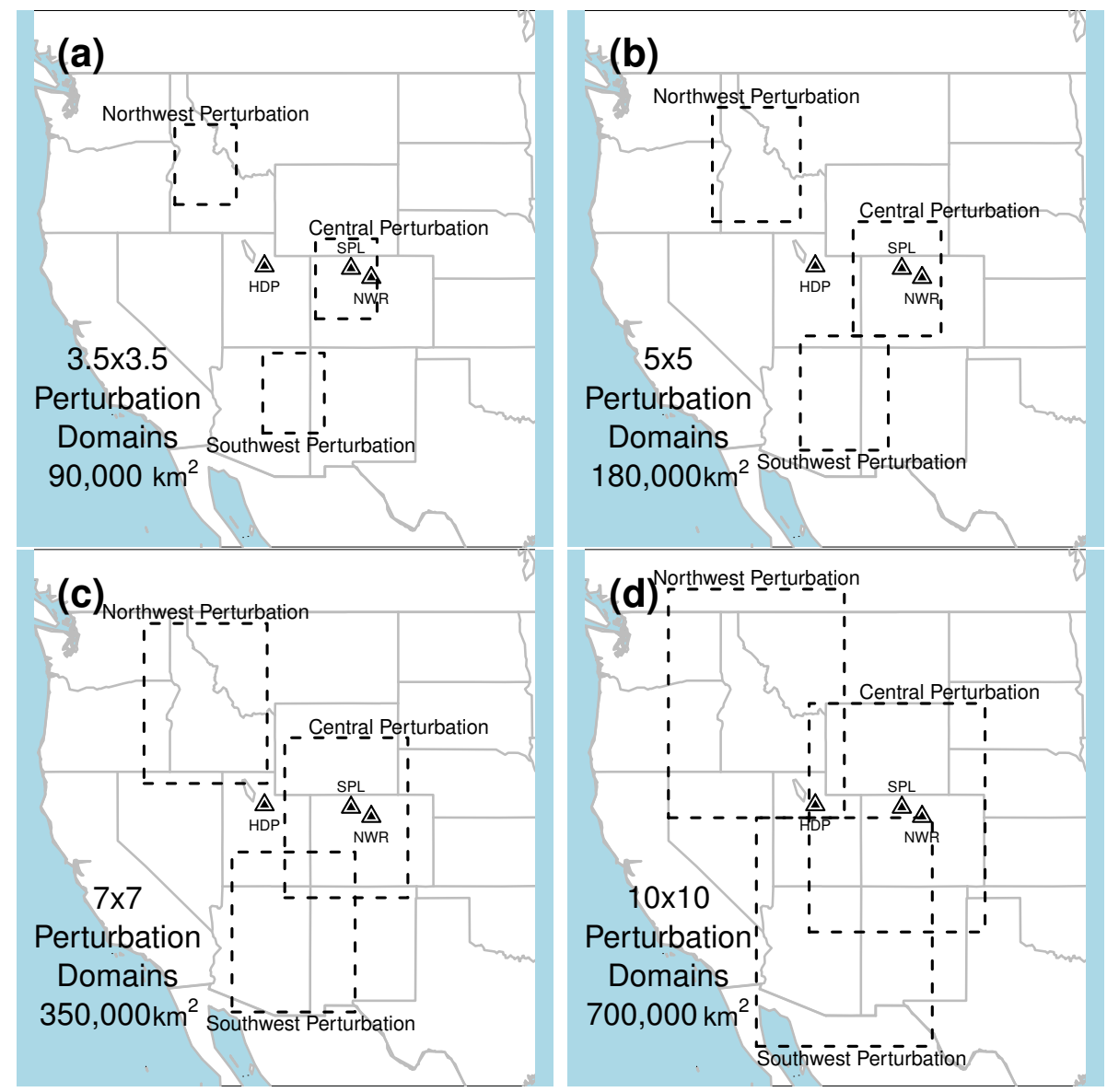

Figure 5. Maps illustrating dimensions and locations of the perturbation domains imposed over the U.S. Mountain West region. 
Biogeosciences Discuss., doi:10.5194/bg-2016-223, 2016

Manuscript under review for journal Biogeosciences

Published: 20 June 2016

(c) Author(s) 2016. CC-BY 3.0 License.

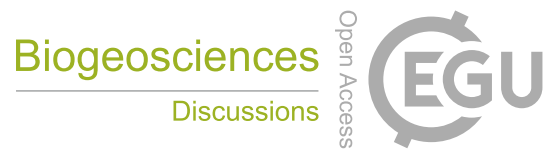

(c) (i)

(a)

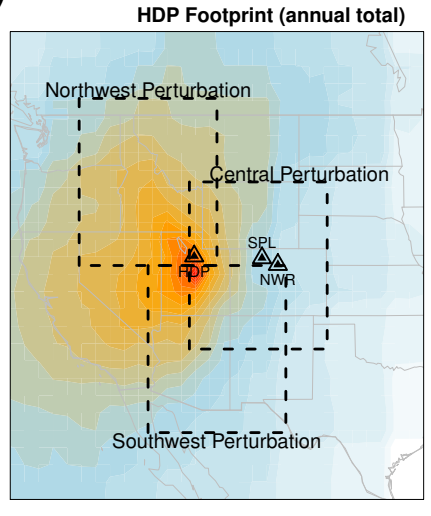

(c)

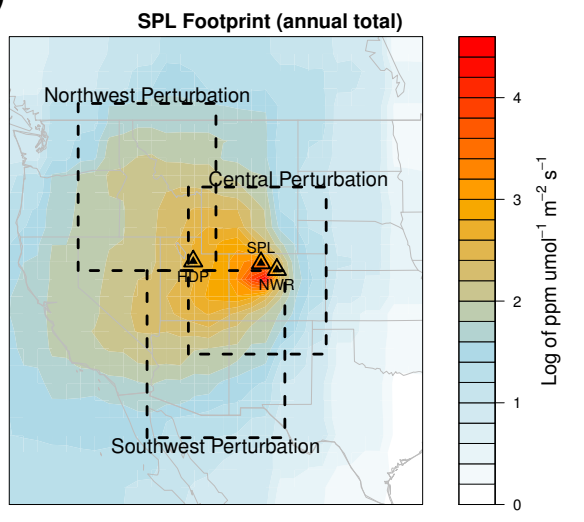

(b)

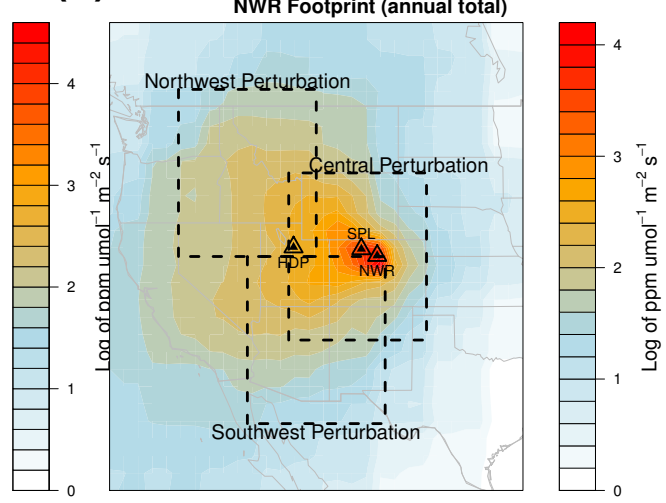

Figure 6. Site footprints for the 2008 year determined by WRF-STILT from 2008 back-trajectory analysis for (a) HDP, (b) NWR, and (c) SPL stations with $10^{\circ} \times 10^{\circ}$ perturbation domains (note log scale). Although the $\mathrm{CO}_{2}$ footprints of these mountaintop stations are orders of magnitude larger than the flux footprint of eddy covariance towers, the proximity to site is important to $\mathrm{CO}_{2}$ concentration observation. 
Biogeosciences Discuss., doi:10.5194/bg-2016-223, 2016

Manuscript under review for journal Biogeosciences

Published: 20 June 2016

(c) Author(s) 2016. CC-BY 3.0 License.

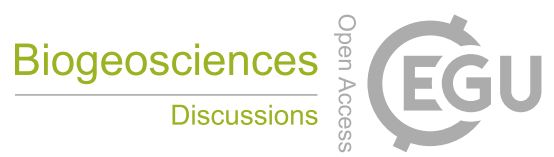

(c) (i)

(a)

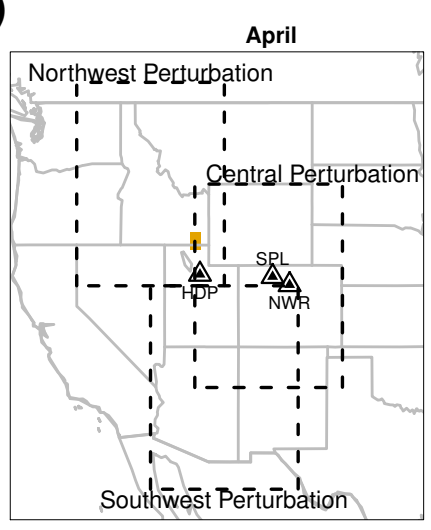

(c)

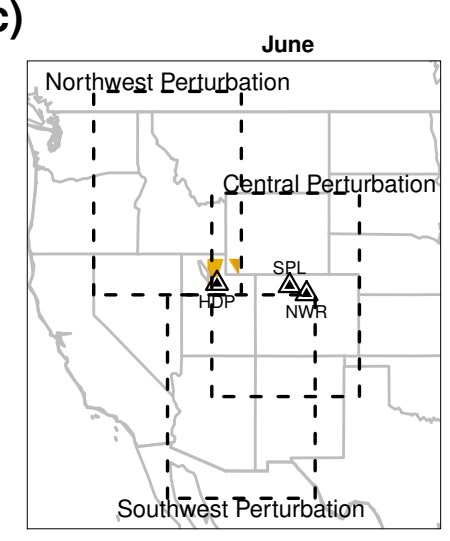

(b)

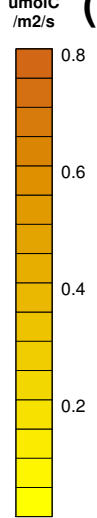

$\underset{\mathrm{um} 2 / \mathrm{s}}{\mathrm{umolC}}$

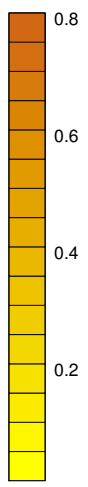

Figure 7. Prototypical carbon cycle perturbation from VEGAS DGVM (Zeng et al., 2005) with $10^{\circ} \times 10^{\circ}$ domains for comparison. 
Biogeosciences Discuss., doi:10.5194/bg-2016-223, 2016

Manuscript under review for journal Biogeosciences

Published: 20 June 2016

(c) Author(s) 2016. CC-BY 3.0 License.
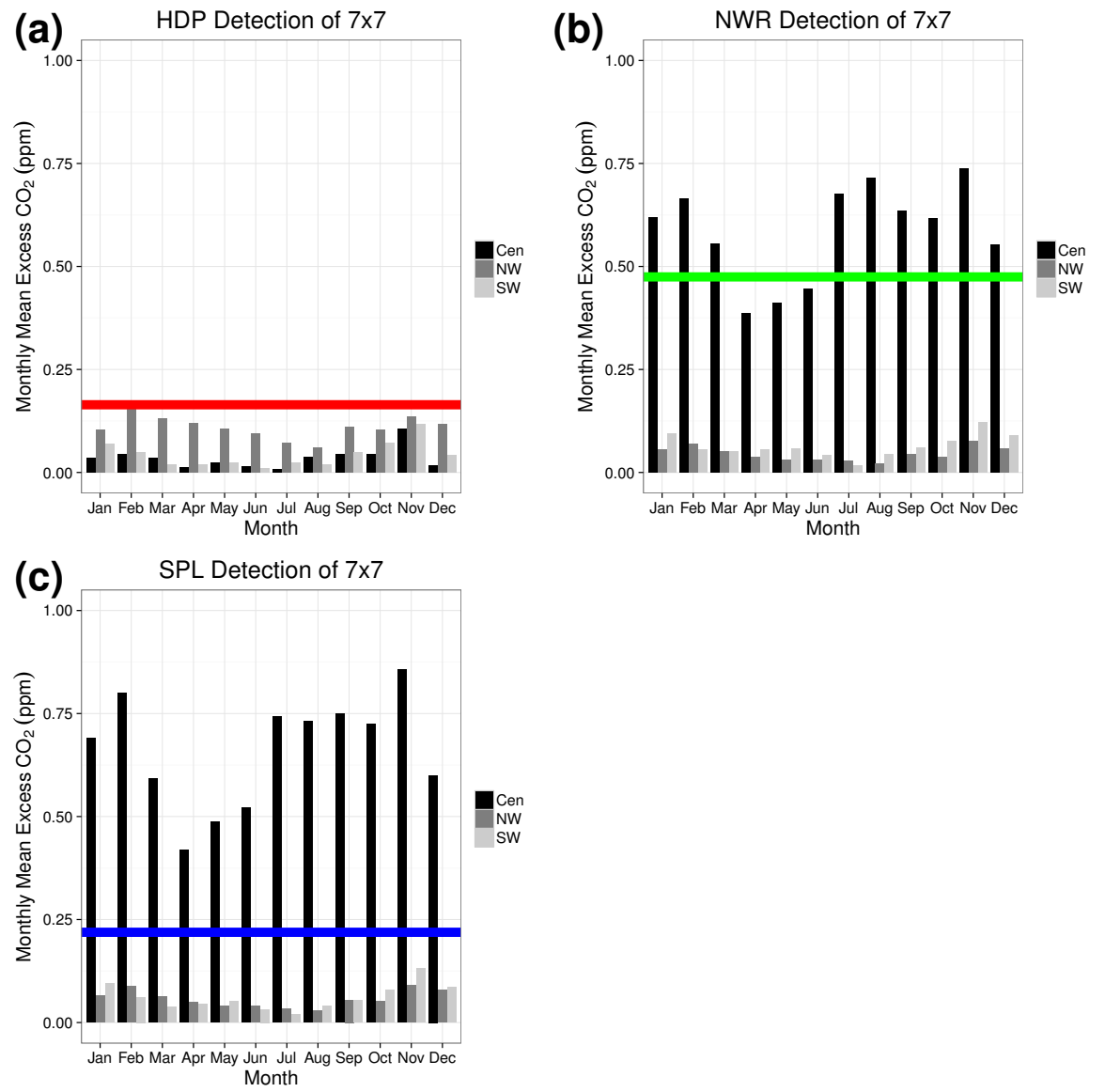

Figure 8. Monthly mean excess $\mathrm{CO}_{2}$ values for $7^{\circ} \mathrm{x} 7^{\circ}$ perturbations are indicated by the height of the vertical bars. Figure panels a-c distinguish the three measurement stations HDP, NWR, and SPL respectively. This figure is the same as Fig. 4 except that the perturbation is one-half the area $\left(7^{\circ} \times 7^{\circ}\right.$ not $\left.10^{\circ} \times 10^{\circ}\right)$ and it excludes the prototypical perturbation. The same station-specific MDM detection thresholds are used. 
Biogeosciences Discuss., doi:10.5194/bg-2016-223, 2016

Manuscript under review for journal Biogeosciences

Published: 20 June 2016

(c) Author(s) 2016. CC-BY 3.0 License.

\section{(c) (i)}

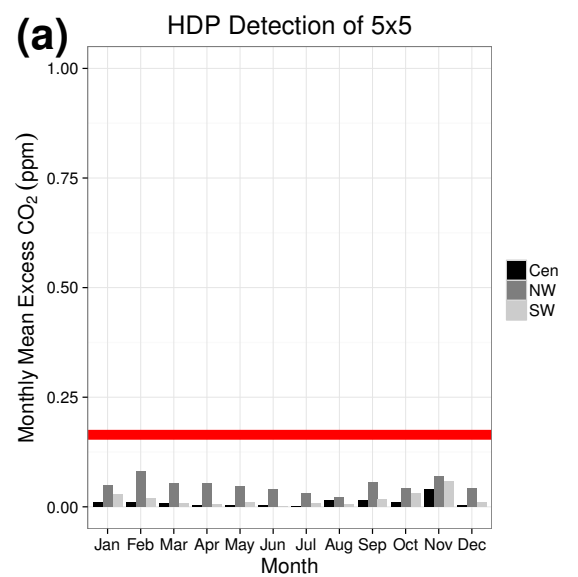

(c)

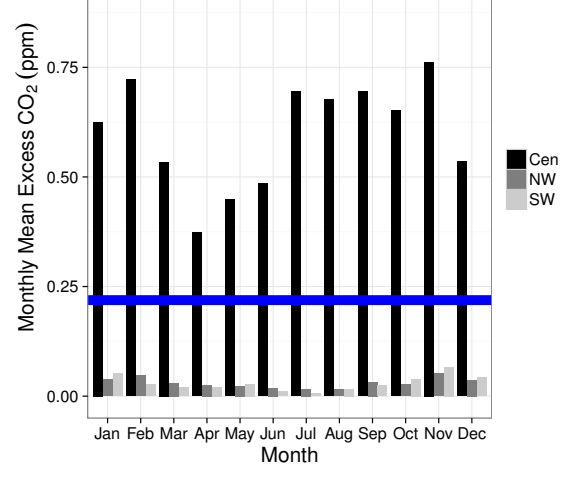

(b) NWR Detection of $5 \times 5$

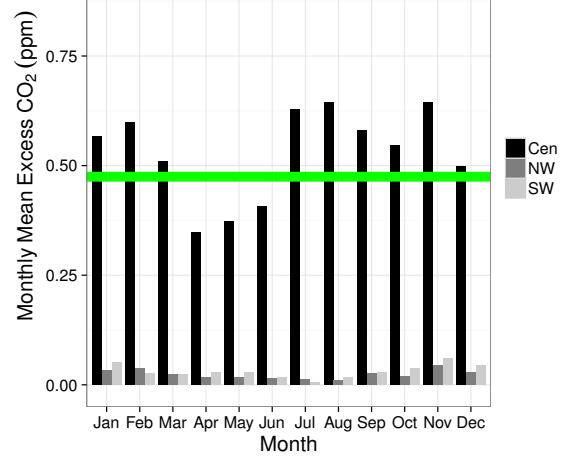

Figure 9. Monthly mean excess $\mathrm{CO}_{2}$ values for $5^{\circ} \mathrm{x} 5^{\circ}$ perturbations. Same as Fig. 4 except that the perturbation is one-fourth the area and it excludes the prototypical perturbation. 
Biogeosciences Discuss., doi:10.5194/bg-2016-223, 2016

Manuscript under review for journal Biogeosciences

Published: 20 June 2016

(c) Author(s) 2016. CC-BY 3.0 License.

\section{(c) (i)}

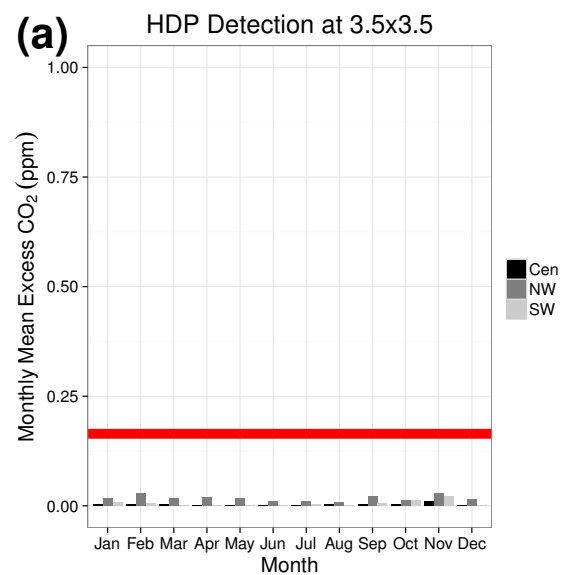

(c)

C) SPL Detection at $3.5 \times 3.5$

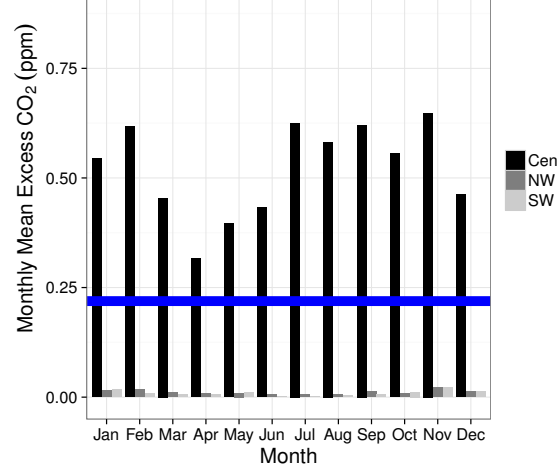

(b) NWR Detection at $3.5 \times 3.5$

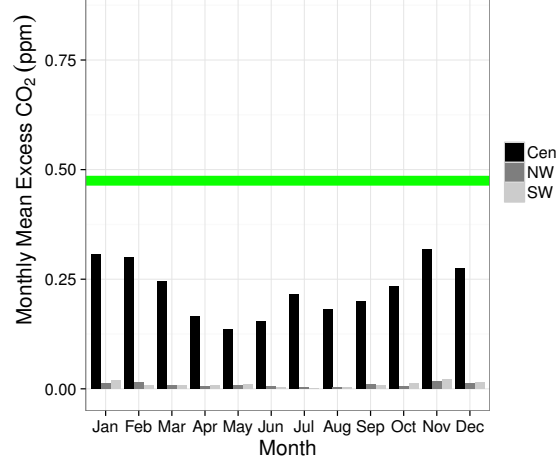

Figure 10. Monthly mean excess $\mathrm{CO}_{2}$ values for $3.5^{\circ} \times 3.5^{\circ}$ perturbations. Same as Fig. 4 except that the perturbation is one-eighth the area and it excludes the prototypical perturbation. 
Biogeosciences Discuss., doi:10.5194/bg-2016-223, 2016

Manuscript under review for journal Biogeosciences

Published: 20 June 2016

(c) Author(s) 2016. CC-BY 3.0 License.

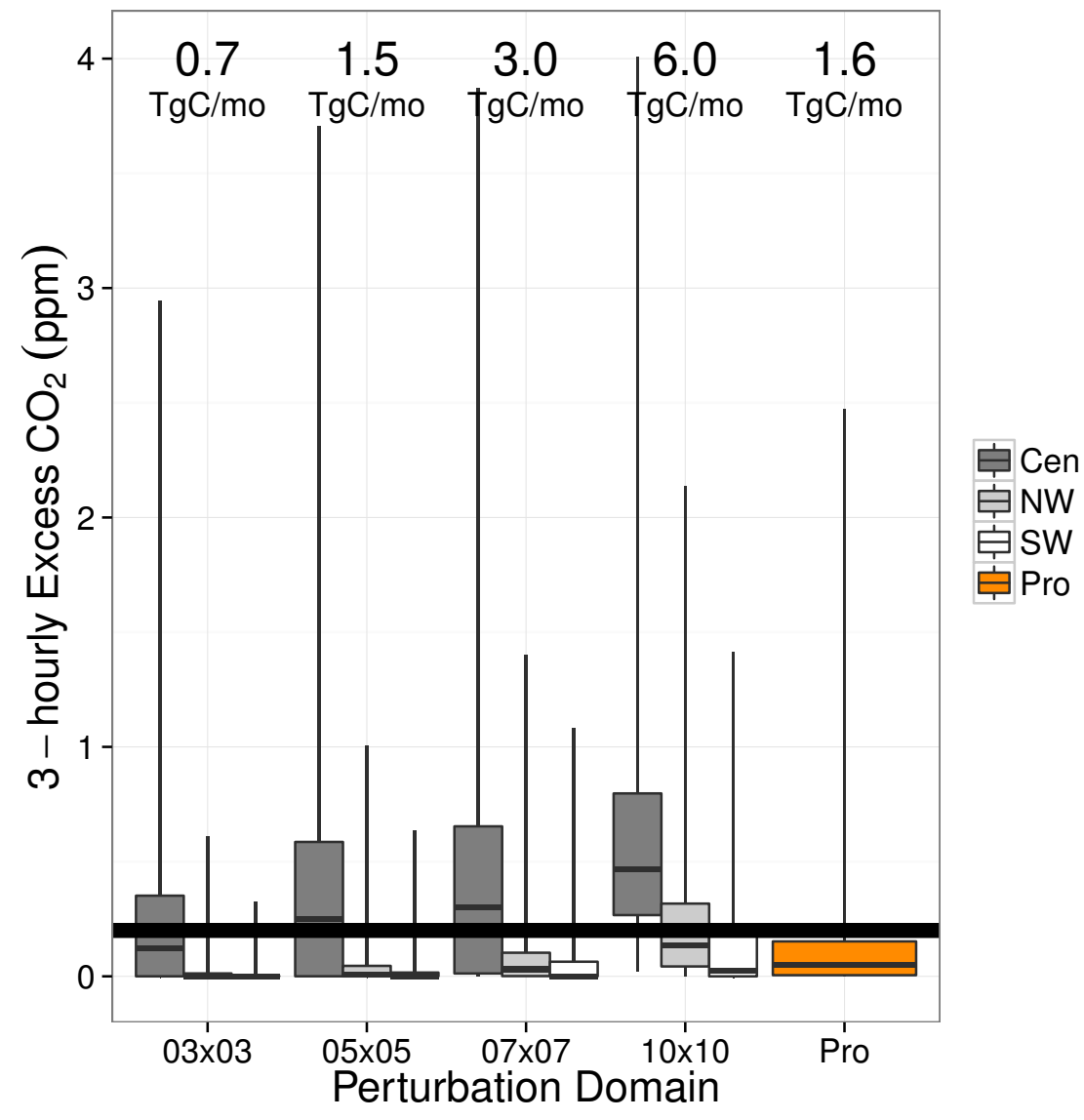

Figure 11. Combined (3 stations) 3-hourly excess $\mathrm{CO}_{2}$ by perturbation size and perturbation location. Box and whisker quantiles from 3-hourly excess $\mathrm{CO}_{2}$ values from the three $\mathrm{CO}_{2}$ stations are shown for differently positioned perturbations. The horizontal line indicates the $0.2 \mathrm{ppm}$ measurement error threshold. Each box and whisker for Cen, NW, and SW represent data points from all 3-hourly values throughout the year, while Pro only represents values during the 3 drought months (April-June). The change in excess $\mathrm{CO}_{2}$ with increasing perturbation area is shown from left to right, except prototypical, which has an area between the $5^{\circ} \times 5^{\circ}$ and $7^{\circ} \times 7^{\circ}$ scales. Perturbation magnitude, as monthly mean from the annual total, is shown for each perturbation size across the top. 